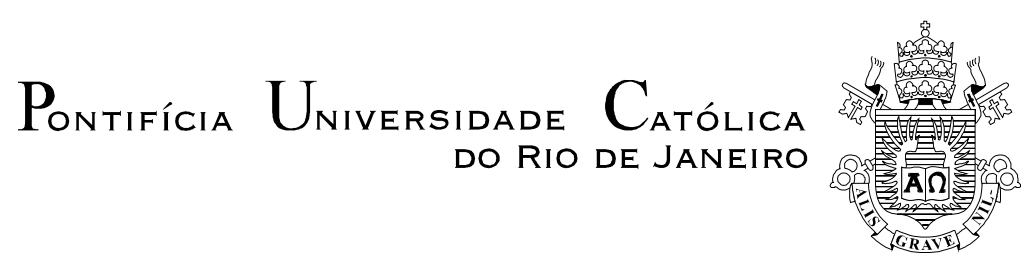

Renata de Oliveira Rodrigues dos

Santos

\title{
Pensamento Político Brasileiro: representações da Ibéria
}

Dissertação apresentada ao Programa de Pósgraduação em Ciências Sociais da PUC-Rio como requisito parcial para obtenção do título de Mestre em Ciências Sociais.

Orientador: Prof. Valter Sinder Co-orientador: Prof. Paulo Mesquita d'Avila Filho 


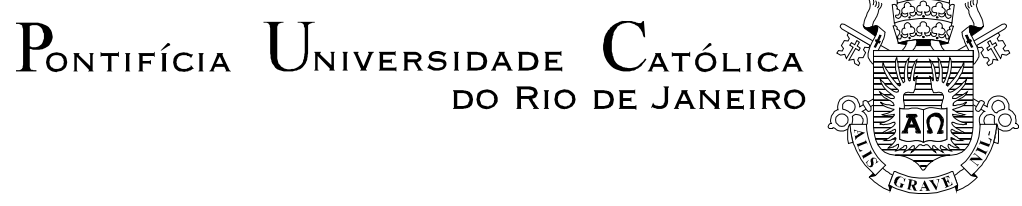

Renata de Oliveira Rodrigues dos Santos

\section{Pensamento Político Brasileiro: representações da Ibéria}

Dissertação apresentada como requisito parcial para obtenção do título de Mestre pelo Programa de Pós-Graduação em Ciências Sociais da PUCRio. Aprovada pela Comissão Examinadora abaixo assinada.

Prof. Valter Sinder Orientador

Departamento de Ciências Sociais - PUC-Rio

Prof. Paulo Mesquita d'Avila Filho Co-Orientador UERJ

Profa. Aparecida Maria Abranches UFRRJ

Prof. Paulo Jorge da Silva Ribeiro Departamento de Ciências Sociais - PUC-Rio

Profa. Mônica Herz Coordenadora Setorial do Centro de Ciências Sociais - PUC-Rio

Rio de Janeiro, 21 de setembro de 2012 
Todos os direitos reservados. É proibida a reprodução total ou parcial do trabalho sem autorização da universidade, do autor e do orientador.

\section{Renata de Oliveira Rodrigues dos Santos}

Graduou-se em Ciências Sociais pela PUC-Rio em 2009.

Interessada nas questões sobre identidade cultural.

Ficha Catalográfica

Santos, Renata de Oliveira Rodrigues dos

Pensamento político brasileiro: representações da Ibéria / Renata Rodrigues dos Santos ; orientador: Valter Sinder ; co-orientador: Paulo Mesquita d'Avila Filho. -2012. $93 \mathrm{f.} ; 30 \mathrm{~cm}$

Dissertação (mestrado)-Pontifícia Universidade Católica do Rio de Janeiro, Departamento de Ciências Sociais, 2012. Inclui bibliografia

1. Ciências Sociais - Teses. 2. Pensamento político brasileiro. 3. Estudos culturais. 4. Identidades culturais. 5. Representação. 6. Iberismo. 7. Cultura ibérica. I. Sinder, Valter II. d'Avila Filho, Paulo Mesquita III. Pontifícia Universidade Católica do Rio de Janeiro. Departamento de Ciências Sociais. IV. Título.

CDD: 300 

saber, mamãe e vovó. 


\section{Agradecimentos}

Ao meu Deus, porque dEle, por Ele e para Ele são todas as coisas.

Ao meu marido, pelo companheirismo e paciência. Amo você.

À minha família, por acreditarem mais em mim do que eu mesma. Por sempre ser um porto seguro. A cada dia amo mais vocês.

Ao meu orientador, Valter Sinder, por aceitar o desafio.

Ao Paulo d'Avila Filho, co-orientador, pelas instigantes reflexões que me inspiram desde a graduação.

À PUC-Rio e ao Departamento de Sociologia e Política, aos professores e funcionárias por todo apoio e dedicação.

À CAPES e à PUC-Rio, pelos auxílios concedidos, sem os quais este trabalho não poderia ter sido realizado. 


\section{Resumo}

Santos, Renata de Oliveira Rodrigues dos; Sinder, Valter. Pensamento

Político Brasileiro: Representações da Ibéria. Rio de Janeiro, RJ, 2012.

93p. Dissertação de Mestrado - Departamento de Ciências Sociais,

Pontifícia Universidade Católica do Rio de Janeiro.

A presente dissertação pretende discutir duas representações distintas da Ibéria, presentes no pensamento social brasileiro, a partir do debate travado entre Simon Schwartzman e Richard Morse, por ocasião do lançamento do livro deste último, O Espelho de Próspero. Entende-se que a representação de uma sociedade é marcada pelo discurso construído a respeito dela. A compreensão de como discursos divergentes "competem" entre si, aliado à perspectiva de que o discurso é construído e funciona como instrumento de poder, poderá enriquecer o debate em torno da nossa, sempre em construção, identidade, produzindo uma compreensão mais rica sobre nós mesmos.

\section{Palavras-chave}

Pensamento Político Brasileiro; Estudos Culturais; Identidades Culturais; Representação; Iberismo; cultura ibérica. 


\section{Abstract}

Santos, Renata de Oliveira Rodrigues dos; Sinder, Valter (Advisor).

Brazilian Political Thought: Representations of Iberia. Rio de Janeiro, RJ, 2012. 93p. MSc. Dissertation - Departamento de Ciências Sociais, Pontifícia Universidade Católica do Rio de Janeiro.

This dissertation discusses two distinct representations of Iberia, illustrated in brazilian social thought, from the debate between Simon Schwartzman and Richard Morse, due to the occasion of the book release of the latter, O Espelho de Próspero. It is understood that the representation of a society is marked by a discourse constructed about it. The comprehension of how divergent discourses "compete" with each other, allied to the perspective that discourse is constructed and works as an instrument of power, will be able to enrich the debate of our everbuilding identity, producing a richer understanding about ourselves.

\section{Palavras-chave}

Brazilian Political Thought; Cultural Studies; Cultural Identity; Representation; Iberism; Iberian culture. 


\section{Sumário}

1 Introdução 10

2 Discurso, representação e identidade. 19

2.1. Discurso 19

2.1.1. Saber e Poder 19

2.1.2. Ciências Sociais e o conceito de modernidade 26

2.2. História e Representação 29

2.3. Identidade $\quad 35$

2.3.1. Três concepções de identidade $\quad 37$

2.3.2. O descentramento do sujeito $\quad 39$

2.3.3. Considerações finais 42

3 O debate entre Morse e Shwartzman $\quad 44$

3.1. Introdução 44

3.2. O pivô do debate: $O$ Espelho de Próspero 47

3.3. A crítica: $O$ Espelho de Morse 56

3.4. A réplica: A Miopia de Schwartzman 59

3.5. A tréplica: $O$ Gato de Cortázar 61

3.6. Conclusão 63

4 Sujeitos em construção, representações em disputa. 66

4.1. Sujeitos construídos 66

$\begin{array}{ll}\text { 4.1.1. O sujeito que pesquisa } & 70\end{array}$

4.2. Duas formas de olhar 72

4.2.1. Duas formas de compreender o trabalho científico 73

4.2.2. Duas formas de compreender o processo histórico 76

4.3. Pano de fundo moral 78

4.3.1. Representação como espelho 83

5 Considerações finais $\quad 85$ 
"A gente sempre escreve o que ouve, nunca o que houve." Oswald de Andrade 


\section{Introdução}

Em 1988, Richard Morse, americano, brasilianista para alguns, publica $O$ Espelho de Próspero. Nele, procura traçar um panorama da civilização ocidental, explorando a capacidade de alternativa civilizacional de uma de suas vertentes. Uma vertente que tem sido desprezada: a tradição ibérica. Morse a apresenta como detentora de algo especial, que pode servir como antídoto aos esgotados ideais do Norte.

Schwartzman, brasileiro, lê o livro. E não se sente bem. Identifica ali um perigo e, assim, publica imediatamente um artigo com o objetivo de alertar aos seus leitores: não caiam no "canto da sereia!” Qual canto? O entoado por Morse, que procura nos iludir, colocando a América Ibérica como espelho para a América Anglo-Saxã.

Assim tem início o "debate", objeto deste trabalho, que conta, ainda, com mais dois artigos, um de cada autor. Enquanto debatem, dissertam sobre projetos políticos. Enquanto debatem, constroem seus discursos sobre a história, criando representações, da Europa, das Américas. Enquanto debatem, participam do jogo da formação de identidades.

Isso porque a referência aos nossos ex-colonizadores e a uma "herança ibérica" é uma das possibilidades, um dos caminhos possíveis para se pensar o Brasil. E, "pensar o Brasil" é produzir discursos sobre ele. Dentro desses discursos, segundo Hall, são produzidos sentidos sobre a nação, permitindo processos de identificação. E esses sentidos estão, em grande medida, nas memórias, nas histórias que nos contam sobre o passado.

Katheyn Woodwart chama atenção ao fato de que esse resgate fala mais sobre o presente do que sobre o passado mesmo. Ou seja, o elemento resgatado fala mais de sua posição na construção da identidade presente, do que sobre ele mesmo no passado. $\mathrm{O}$ resgate, portanto, obedece à lógica do presente, porém, não necessariamente por intenção deliberada de dolo por parte do intérprete, mas 
porque a moldura com a qual ele olha revela seu compromisso com o presente e impacta ou organiza seu olhar sobre o passado.

A moldura, assim, se revela importante, porque organiza o olhar. O que, então, informa essas molduras? Do que são constituídas? O que faz com que esse "resgate do passado" ganhe tonalidades tão distintas?

Já na graduação, esse ponto me instigava, ainda que não com os contornos, ou com os termos atuais. $\mathrm{Na}$ ocasião, analisando outros autores, me instigava o fato de, embora "resgatando" o mesmo elemento do passado, lhe atribuíssem sentidos, valores, tão distintos. Naquele momento, resolvi meus questionamentos com Foucault, enveredando pela argumentação de que estes posicionamentos estão imersos em disputas políticas, sujeitos a relações de poder.

Aqui, neste trabalho, decidi persistir na minha busca. Existem relações de poder? Sim. Sempre. No entanto, eu precisava continuar. MacIntyre me sugere a ir atrás do que está na base de cada representação. Então, escolhi continuar a partir da análise das molduras, distintas, com as quais os autores operam. Como seus olhares são diferentemente direcionados? Nesse processo, destaquei duas principais distinções: 1) os autores possuem compreensões distintas sobre a natureza e o objetivo do trabalho científico; 2) os autores possuem distintas compreensões de como se dá o processo histórico.

Essas diferenças formatam as molduras com as quais nossos autores operam, orientando seus olhares.

O trabalho de Taylor, no entanto, nos ensina que essas molduras não estão no vazio, mas num ambiente moral. Esse ponto, aliado à reflexão de Butler, de que toda teoria postula fundamentos, que funcionam como seus inquestionáveis, me permitiram/impulsionaram a refletir sobre quais seriam os fundamentos dessas representações. O que estaria na base? O que é o inquestionável de Morse e de Schwartzman?

Quando eu era criança, participava de muitos debates bíblicos. Eu adorava. O princípio nesses "debates", a hermenêutica bíblica, é de que a Bíblia se explica por ela mesma. Ela é o fundamento inquestionável. Eu era boa, convincente. Quando, no entanto, comecei a me aventurar a debates fora do "círculo bíblico", comecei a perceber que meu princípio hermenêutico não valia muito. De nada adiantava eu argumentar: "mas está escrito na Bíblia...”. Eu ouviria, sem nenhuma hesitação da outra parte, algo como: "e daí?". 
Assim como eu tinha a Bíblia (e ainda tenho, mas aprendi a utilizá-la onde aceitam a sua hermenêutica), entendo que Morse e Schwartzman também tem seus inquestionáveis, o valor que está fora do debate. Esses valores funcionam como o princípio organizador dos seus respectivos ideais de sociedade. Schwartzman tem seu valor fundamental no indivíduo e, assim, todo argumento, toda proposta política que o questione, não será digna de consideração, como meus argumentos fora do círculo bíblico. Ou, nas palavras de MacIntyre, fora da racionalidade da sua tradição. Da mesma forma, Morse não admite nenhuma proposta política ou argumento que coloque o indivíduo em primeiro lugar, em detrimento da sociedade. Não aceita nada que quebre a organicidade que, para ele, não pode ser gerada de dentro para fora (ou seja, do indivíduo para o todo), mas deve ser gerada do todo para o indivíduo.

Tendo em mente o pano de fundo moral que nos permeia (Taylor, 1997), chamo atenção para a relação existente entre o valor fundamental com o qual cada autor opera, seu ideal de sociedade e seus respectivos projetos políticos - o "dever ser" que possuem.

Ambos os autores falam de uma posição de desencanto. Desencantados com suas próprias sociedades buscam no outro uma alternativa civilizacional e cultural e, nesse movimento, negam suas sociedades de origem. Para Morse, os Estados Unidos encontram-se numa situação de esgotamento dos seus ideais civilizacionais e encontra no seu outro, a Ibero-América, a alternativa. Para Schwartzman, a América Latina tem sido sinônimo de obscurantismo e autoritarismo e, igualmente, encontra no seu outro, os Estados Unidos e a Europa, sua alternativa.

Morse inicia seu livro propondo a inversão do espelho que tem sido insistentemente mostrado à América-Ibérica e percebemos, neste debate, que ambos os autores manipulam esse espelho, cada um a sua maneira, de forma a alcançar sua própria "imagem ideal” ali refletida.

O tema deste trabalho são as representações da Ibéria. O objeto, as representações da cultura ibérica criadas no debate entre Richard Morse e Simon Schwartzman. Meu objetivo é observar como essas construções, além de estarem em disputa, são formadas a partir de diferentes molduras interpretativas e 
diferentes perspectivas normativas sobre o dever ser. Na chave desenvolvida nesta dissertação, os olhares sobre a Ibéria revelam, sobretudo, distintas percepções sobre o Brasil e diferentes projetos políticos.

Num primeiro momento, apresento a perspectiva pela qual o objeto é compreendido, discutindo três pontos principais: a produção dos discursos, a representação e a construção de identidades. Dessa forma, exponho meu enquadramento do tema, ou seja, entendo o debate dos autores, apresentado num segundo momento, como discursos produzidos sobre a cultura ibérica que, na medida em que são construídos, conformam identidades que estão em constante disputa pela posição de narrativa vencedora. Assim, o debate travado entre Morse e Schwartzman neste trabalho é compreendido como representações da Ibéria em disputa. Meu objetivo não é chegar à conclusão de qual narrativa venceu a disputa, tampouco qual deles chegou mais próximo da realidade. Ao contrário, acredito que ambos os autores narram essa realidade a partir do seu ponto de vista que, conforme desenvolvo em outro momento do trabalho é, em grande medida, conformado por seus respectivos enquadramentos.

O interesse pela cultura ibérica surgiu ainda na graduação, nas aulas de pensamento social brasileiro. Despertava minha curiosidade o fato de os intérpretes do Brasil apresentarem diagnósticos negativos em relação a nossa história, impondo como condição de acesso ao "moderno" a ruptura com "nosso tradicionalismo", a fim de que seguíssemos uma trajetória semelhante aos ditos modernos Estados Unidos, Inglaterra ou França.

No terceiro ou quarto período ingressei numa pesquisa de iniciação científica, Matrizes do Pensamento Político Moderno: O caso ibérico, sob orientação do Prof. Paulo M. d'Avila Filho. A leitura introdutória ao plano de pesquisa, o livro Tradição e Artifício - Barroco e iberismo na formação americana, de Rubem Barboza Filho, no entanto, provocaram as inquietações que seguem até este trabalho. Nesta obra, o autor realiza uma exaustiva pesquisa sobre a história e filosofia ibéricas e, à página 101 apresenta a tese do livro, a Ibéria como variante civilizacional do Ocidente. Minha principal referência a respeito da Ibéria, até este momento, era Raymundo Faoro, para o qual Portugal e Espanha representam a Europa que não deu certo. Nas suas obras, Faoro transmite a imagem de que Portugal é uma mancha negra no nosso passado, que traz consequências negativas até o presente. 
As representações da Ibéria criadas por Faoro e Barboza foram objeto de um trabalho anterior, minha monografia, na conclusão da graduação. Naquele momento, meu questionamento era como dois autores, apontando a mesma característica da trajetória histórica de Portugal e Espanha - o territorialismo ibérico - criam representações tão distintas desta cultura. Enquanto Barboza a classifica como "variante civilizacional do Ocidente", Faoro a chama de "caso frustrado do capitalismo". Na monografia, começando a ler Foucault, analisei a produção dos autores sob a perspectiva de que não existe saber neutro, o saber científico também está imerso em relações de poder.

A pesquisa desenvolvida durante a graduação, cujo resultado foi a monografia, não foi suficiente, no entanto, para responder ao questionamento mais interior, aquele que mexe com minhas paixões mais profundas. Por que, afinal, dois autores, olhando para a mesma característica, tem posicionamentos tão diferentes, para não dizer opostos. Decidi, então, seguir a pesquisa no mestrado, e este é o trabalho que apresento aqui.

O presente trabalho conta com uma diferença essencial em relação ao anterior. Tem o mesmo objeto de análise, ou seja, representações da cultura ibérica, porém, de autores diferentes. A mudança dos autores deve-se a uma crítica recebida durante a graduação, ou seja, a de que eu comparava autores distantes no tempo. A troca, no entanto, vem reforçar meu posicionamento anterior, de que as formas de pensar de Faoro e Barboza, apesar de distantes no tempo, não são retratos dos seus respectivos contextos históricos, mas sim expressões de diferentes enquadramentos com os quais os autores operam. $\mathrm{O}$ debate escolhido para ser o objeto deste trabalho demonstra isso. São autores contemporâneos um ao outro, com formas de pensar semelhantes às de Faoro e Barboza. Dessa forma, procuro expor meu entendimento de que essas formas de pensar não tem como pano de fundo o contexto histórico de seus autores, mas sim diferentes compreensões de como os processos sociais ocorrem que, por sua vez, estão relacionadas a diferentes concepções de bem, nas palavras de Charles Taylor.

Este trabalho, no entanto, se insere num campo maior que meus questionamentos pessoais. Nas Ciências Sociais, em geral, buscando compreender os fenômenos humanos a partir de aspectos culturais, políticos e sociais, criamos e mobilizamos representações das sociedades e dos grupos com os quais 
trabalhamos. Assim, as representações são, ao mesmo tempo, fonte e resultado do nosso trabalho, o que torna relevante o estudo sobre como estas são criadas, apropriadas, reproduzidas, modificadas.

É comum observarmos no pensamento social brasileiro uma referência constante à cultura ibérica como um caminho para explicar nossa própria constituição social, política e cultural ${ }^{1}$. Olhando para Portugal e Espanha (mais para o primeiro, no caso do Brasil), poderíamos compreender nossa própria trajetória, interpretada como um reflexo da cultura de nossos antigos colonizadores. Dessa forma, compreendendo a trajetória política de Portugal, suas instituições e sua cultura, compreenderíamos a nós mesmos.

A difícil tarefa de se pensar o Brasil pode ser feita por diferentes caminhos, dentre os quais a referência aos nossos ex-colonizadores e a uma "herança ibérica", não é o único, tampouco um caminho natural. Pelo contrário, a escolha desse caminho (e não outro) é resultado de opções teórico-metodológicas feitas pelo pesquisador e de uma forma determinada de entendimento de como os processos sociais, políticos e culturais ocorrem. Entendendo que a representação de uma sociedade é dada através do discurso construído a respeito dela, a compreensão de como estes discursos "competem" entre si poderá enriquecer o debate, produzindo uma compreensão mais rica sobre nós mesmos.

Edward Said (2007), na introdução do seu livro, antes de explicar as questões metodológicas, e até pessoais, envolvidas na escolha e delimitação do tema, se detém num ponto relevante para os objetivos do meu trabalho: a distinção entre o conhecimento puro e o conhecimento político. Apesar da exigência da produção de um conhecimento apolítico, o autor discorda de que, na prática, tal coisa seja possível, pois, em suas palavras, "ninguém jamais inventou um método para distanciar o erudito das circunstâncias da vida" (Said, 2007: 38). A posição de Said é justamente oposta. Segundo o autor, a insistência na ideia de que o "verdadeiro" conhecimento é apolítico confunde porque obscurece as relações de poder que lhe são inerentes.

Persiste neste trabalho, portanto, o objetivo de investigar as relações de poder presentes na produção dos discursos. Por isso, os trabalhos de Michel Foucault continuam sendo de extrema relevância para as reflexões aqui

\footnotetext{
${ }^{1}$ Essa referência é observada nas ex-colônias da América do Sul de uma forma geral, tanto de origem espanhola quanto portuguesa. Esse trabalho, no entanto, se restringirá ao caso brasileiro.
} 
pretendidas. Seu conceito de poder e de micropoderes permitirá pensar as representações sociais sob uma perspectiva política, de disputa. Em seus trabalhos, este autor desenvolve uma profunda reflexão sobre a produção dos discursos e de como estes funcionam como instrumento de poder.

Neste trabalho pretendo, ainda, pensar a construção das identidades. Entendo que quando represento uma sociedade, quando construo um discurso sobre ela, estou participando da construção da sua identidade. Neste sentido serão relevantes os trabalhos de Stuart Hall (2011), que nos permitirá a reflexão a partir de diferentes concepções de sujeito; de Judith Butler (1998), cuja concepção de um sujeito constituído pelas posições que assume será fundamental para reflexão sobre os posicionamentos dos nossos autores em relação à cultura ibérica; e, ainda, de Charles Taylor (1997), que nos permitirá pensar as fontes morais desses posicionamentos.

O trabalho está organizado em capítulos, da seguinte maneira:

No capítulo Discurso, representação e identidade, desenvolvo os marcos teóricos gerais que norteiam todo o trabalho, a partir de quatro pontos principais. No primeiro, discuto a questão da neutralidade do saber, a partir de três conceitos de Michel Foucault: poder, como difuso na sociedade, produto das relações sociais; representação, cuja principal contribuição, para o objetivo deste trabalho, será permitir a reflexão de que não há um lugar fora da disputa do qual seja possível a observação ou a fala; e discurso, como constructo que pré-ordena o enunciado, veículo não neutro, cuja produção e circulação é controlada, sujeita a determinados procedimentos. No segundo ponto, abordo a hierarquização de culturas e sociedades realizada, muitas vezes, na prática das ciências sociais, a partir dos conceitos de "moderno" e "atraso". Nesse sentido, utilizo os conceitos de civilização e cultura, como duas formas de pensar, dois enquadramentos dos processos sociais. No terceiro ponto, discuto o conceito de representação a partir de sua aplicação no fazer historiográfico. Para isso, utilizo o trabalho de Francisco Calazans Falcon (2000), no qual o autor distingue entre duas formas de representação. No último ponto deste capítulo, abordo a questão das identidades como produtos, e não apenas objetos, da representação. Apresento, também, as três concepções de identidade, a partir de Stuart Hall, assim como seu desenvolvimento histórico da concepção de sujeito. 
No capítulo $O$ debate entre Morse e Schwartzman, apresento o objeto de análise do trabalho - o "debate", por ocasião da publicação do livro de Morse, $O$ Espelho de Próspero (1988). No livro, Morse defende a ideia de que as Américas, ibérica e anglo-saxã, partem de um mesmo tronco civilizacional - o Ocidente, mas que, em determinado momento histórico realizam opções políticas distintas. Por isso, conclui que a América Ibérica não pode ser compreendida como um projeto de civilização frustrado, mas como uma civilização em si mesma. Para Morse, os ideais civilizacionais que inspiraram o Norte estão esgotados e o autor identifica na cultura ibérica uma fonte onde estes podem ser renovados. O "debate" tem início, efetivamente, com a publicação do artigo-crítica de Schwartzman, $O$ Espelho de Morse, em outubro de 1988, onde o autor argumenta contra as ideias expostas no livro, das quais a "mais danosa" seria a apresentação da América Ibérica como espelho para a América Anglo-Saxã. A resposta de Morse vem, também em forma de artigo, A Miopia de Schwartzman, no ano seguinte. Neste trabalho, Morse procura responder às críticas, a partir da identificação de três diferenças fundamentais com seu crítico. Schwartzman insiste no debate publicando $O$ Gato de Cortázar, também em 1989. Neste debate, pretendo observar dois pontos principais: a distinta classificação valorativa que os autores fazem da "tradição ibérica" e a igualmente distinta compreensão que os autores têm do trabalho intelectual e do papel da ciência.

Divido o capítulo Sujeitos em construção, Representações em disputa, em três pontos principais. No primeiro, procuro desenvolver, a partir de Judith Butler e Charles Taylor, a ideia de que os sujeitos são constituídos, e o são sobre um pano de fundo moral. Assim, partindo da ideia de que os sujeitos e as identidades são construções sociais, produzidas no embate, pretendo incluir nessa reflexão os próprios autores, Morse e Schwartzman, que, enquanto sujeitos que pesquisam, estão sujeitos às relações de poder e imersos num ambiente moral. Acredito que essa reflexão poderá enriquecer o entendimento das representações por eles criadas. No segundo ponto, busco analisar as diferentes formas de olhar dos nossos autores. Para isso, utilizo o trabalho de Alasdair MacIntyre (1991), no que se refere a sua reflexão sobre a importância da ideia de racionalidade para a definição de distintos padrões de justiça, buscando compreender os padrões de análise em Morse e Schwartzman sob essa perspectiva. Por fim, abordo a questão da moralidade, como exposta no trabalho de Charles Taylor (1997), buscando 
identificar nos autores analisados quais seriam os valores, ou nas palavras de Taylor, o pano de fundo moral sob o qual operam.

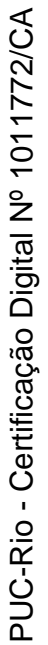




\section{2}

Discurso, representação e identidade.

Como apresentado na introdução, neste capítulo pretendo apresentar o enquadramento analítico do meu objeto. A reflexão sobre a construção dos discursos, das representações e das identidades será feita a partir de quatro pontos fundamentais: a questão da neutralidade do saber, a hierarquização de culturas e sociedades, o conceito de representação e a construção de identidades. O objetivo do capítulo é apresentar a compreensão de que os discursos são instrumentos de poder utilizados nas disputas entre representações. Essas representações, por sua vez, criam identidades, também em disputa.

\section{1.}

Discurso

\subsection{1.}

\section{Saber e Poder}

No processo de institucionalização das Ciências Sociais e seus campos de conhecimento, o estudo da cultura aparece tradicionalmente como especialidade da Antropologia, enquanto o estudo do poder como um tema da Ciência Política. De acordo com o antropólogo Renato Ortiz, no Brasil e nos países latinoamericanos em geral, contudo, esta distinção não é tão clara. Entre nós, "o dilema da identidade nacional levou a intelectualidade latino-americana a compreender o universo cultural como algo intrinsecamente vinculado às questões políticas. Discutir 'cultura' de certa forma era discutir política" (Ortiz, 2004:125).

Os chamados Novos Estudos Culturais refletem essa relação apontada por Ortiz, tendo como uma de suas características a multidisciplinaridade. Tendem a compreender a cultura como "um espaço de convergência de movimentos e ritmos diferenciados: economia, relações sociais, tecnologia etc." (Ortiz, 2004:124). Nesse contexto, não faz sentido separar o estudo da Antropologia do estudo da 
Política. Pelo contrário, significa pensar a cultura, ou seja, a produção, a reprodução e a representação desta, sem perder de vista as relações de poder inerentes às relações sociais, dando especial atenção às zonas de embate, tanto entre Cultura e Política, quanto entre as demais "disciplinas" do saber.

A partir de Foucault, compreende-se poder como um produto dinâmico de relações, não como uma entidade metafísica ou estática. Dessa forma, não existe um centro de onde o poder emana, ou pessoas que "tem poder" e outras que "não tem poder" - o poder é produto do jogo social. Como o exemplo que Foucault mesmo utiliza, ele é a centelha entre o embate dos dois gládios (Foucault, 1979). O filósofo afirma também que o poder não é consentimento, apesar de ser possível como efeito da relação de poder. Podemos entender que para Foucault, o que define uma relação de poder é o fato de ser "um modo de ação que não age direta e imediatamente sobre os outros, mas que age sobre sua própria ação" (Dreyfus \& Rabinow, 1995: 243) 2 .

Uma relação de poder se difere de uma relação de violência. Esta última age sobre o corpo, força, destrói, submete. A relação de poder, ao contrário, mantém "o outro" como sujeito de ação. O "uso da violência" e a "aquisição de consentimentos" são indispensáveis ao exercício do poder, mas não constituem seu princípio ou natureza - são seus instrumentos. O exercício do poder é uma ação sobre ações, ou seja, "ele é um conjunto de ação sobre ações possíveis", uma

2 Foucault distingue três "instâncias" do poder: "relações de poder", "relações de comunicação" e "capacidades objetivas", que não devem ser confundidas. "Relações de poder", designa relações entre parceiros, entre indivíduos ou grupos. "Relações de comunicação", apesar de ser a ação de uns sobre outros, e com isso, terem como consequência efeitos de poder, não são o mesmo que relações de poder, que possuem sua especificidade. "Capacidades objetivas", enfim, seria o poder exercido sobre as coisas, o domínio da técnica. "Trata-se de três tipos de relação que, de fato, estão sempre imbricados uns nos outros, apoiando-se reciprocamente e servindo-se mutuamente de instrumento". A coordenação desses três tipos de relação "não é uniforme nem constante", não estão em equilíbrio nas sociedades. Foucault afirma, no entanto, que existem "blocos" onde estes três tipos de relação estão ajustados uns aos outros - as "disciplinas". O autor afirma, ainda, que o processo de disciplinarização das sociedades, a partir do século XVIII, na Europa, representou o ajuste cada vez mais racional destes três tipos de relação, isto é, "entre as atividades produtivas, as redes de comunicação e o jogo das relações de poder". A abordagem da questão do poder a partir do "como" é, pois analisar as "relações de poder" ao invés de "um poder", desviando-se, assim, da ideia de um "poder fundamental" (Dreyfus \& Rabinow, 1995: 241-2). 
"maneira de agir sobre um ou vários sujeitos ativos". Neste sentido, o exercício do poder consiste em "conduzir condutas", "modos de agir sobre as possibilidades de ação de outros indivíduos", ou seja, uma forma de dirigir as condutas dos indivíduos (Idem, 1995: 243).

Em resumo, a diferença entre a relação de poder e a violência é que a primeira age sobre a ação do sujeito. Ao invés de determinar a ação, como na relação de violência, ela como que sugere, influencia. A relação de violência mostra ao sujeito submetido que ele foi vencido e que há um novo "senhor". Ao contrário, a relação de poder mantém a idéia de que o sujeito é independente, de que é "livre" para fazer suas escolhas. Ele continua como sujeito de ação, mas como que condicionado a certas atitudes e não outras.

Nesta chave, compreendemos que as relações sociais engendram relações de poder. A cultura, portanto, pode e deve ser compreendida sob essa perspectiva. A mudança/ reprodução social se efetiva através de embates, disputas entre indivíduos, grupos e instituições. Nessas disputas, instrumentos de poder são mobilizados, dentre os quais destaca-se o "discurso".

O discurso, segundo Foucault, "não é somente aquilo que traduz as lutas e os sistemas de dominação, mas aquilo por que, pelo que se luta, o poder do qual nos queremos apoderar" (Foucault, 1999: 10). Em A Ordem do Discurso (1999), o filósofo demonstra que a produção e circulação dos discursos é controlada, sujeita a determinados tipos de procedimentos. Segundo o autor, essas interdições mostram que o discurso não é neutro, revelando "sua relação com o desejo e o poder" (Idem, 1999: 10).

Dentre estes dispositivos de controle, quero me deter naquele que o autor chama oposição entre verdadeiro e falso ou "vontade de verdade" (Idem, 1999: 13,19), pois é o que demonstra mais relevância para o ponto desenvolvido neste trabalho. Segundo o filósofo, de dentro do discurso, a separação entre verdadeiro e falso não é arbitrária, ela obedece à lógica que preside o discurso. Portanto, é somente quando, a partir da desnaturalização desses discursos, passamos a compreendê-los como construções, que podemos perceber a existência desse "sistema de exclusão" (Idem, 1999: 14). É neste mesmo sentido que o autor afirma que, apesar de este sistema ser tão poderoso, ele se esconde - e é justamente nisso que reside sua força. Nas palavras do filósofo: o discurso verdadeiro "não pode reconhecer a vontade de verdade que o atravessa; e a 
vontade de verdade, essa que se impõe a nós há bastante tempo, é tal que a verdade que ela quer não pode deixar de mascará-la" (Idem, 1999: 20).

Poderíamos dizer que Richard Rorty (2005), identificou esta vontade de verdade atravessando os argumentos dos filósofos que defendem a política democrática. Estes concordam, geralmente com três pontos: 1) desejo universal pela verdade; 2) verdade corresponde à realidade; 3) realidade tem natureza intrínseca. Para estes filósofos, caminhar na direção desses pontos é caminhar rumo a um estágio de maior agregação, a um estágio mais includente (Rorty, 2005: 104). Contribui nessa argumentação a definição de racionalidade como "faculdade inata orientada para a verdade" (Rorty, 2005: 105). Assim, quanto mais "orientada para a verdade" uma argumentação, "mais racional" ela será e, logo, mais democrática. Dessa forma, essas três premissas são tomadas como exigências da razão, sendo que são estas mesmas que serão elencadas como “constitutivas da ideia de racionalidade" (Rorty, 2005: 105) ${ }^{3}$.

Para se opor ao conceito de verdade, Rorty propõe o de justificação (Rorty, 2005:105). De acordo com o autor, a primeira é irreconhecível, porque não há como ter certeza de que chegamos lá, enquanto a segunda é passível de ser conhecida. Rorty nega a ideia de verdade simplesmente porque não podemos trabalhar com algo que não conhecemos - como não sei o que é a verdade, não posso me guiar por ela. Argumentos de validade universal são igualmente impossíveis. Tudo o que podemos fazer é concordar com algo e construir ao redor disso, o que só é possível abandonando a esperança da neutralidade e aceitando o uso da retórica (Rorty, 2005: 111). Para Rorty, a ideia de verdade serve apenas para "sinalizar para um tipo especial de perigo" (Rorty, 2005: 113) - o de que suas alegações podem ser refutadas perante audiências futuras, ou seja, de que, no futuro, talvez não seja possível justificar a crença atual.

A busca de Rorty, da qual me aproprio neste trabalho, é deslocar o foco de uma fundamentação na verdade (irreconhecível, portanto, impossível) para uma competição por adeptos. A discussão sobre verdade, nos termos em que Rorty a realiza, opondo justificação e verdade, nos permite organizar dois tipos de

\footnotetext{
${ }^{3}$ MacIntyre (1991) discute essa ideia quando afirma que a ideia de racionalidade é tomada, muitas vezes, como argumento de convencimento no embate entre tradições, sendo que ela própria também é definida dentro da tradição à qual se pertence.
} 
argumentos. De um lado, os verdadeiros que, apelando à universalidade ${ }^{4}$, buscam uma superioridade inquestionável e, dessa forma, se retiram da disputa política. Do outro lado, os argumentos justificáveis que, sem apelar ao "inquestionável”, se aceitam completamente imersos na disputa. Nestes fica evidente o caráter construído da coisa, ou seja, é humano e, portanto, pode ser modificado. Não se pretende universal, nem absoluto - a alteridade é possível. E, assim, me parece bem mais democrático. A "vontade de verdade", nos termos de Foucault, apoiase, portanto, numa estrutura institucional que trabalha a seu favor e, dessa forma, "tende a exercer sobre os outros discursos [...] uma espécie de pressão e como que um poder de coerção" (Foucault, 1999: 18). Dessa forma, podemos compreender o poder do discurso verdadeiro, que tem força, inclusive, para ser um estruturante dos demais discursos Nesse sentido, compreendemos também o poder do discurso científico, pois é o discurso apoiado sobre a ideia de verdade. Dessa forma, a ciência aparece como um grande instrumento de poder, na medida em que não apenas ela mesma é um discurso, como fornece as bases (regras, métodos) para a formação dos discursos sobre a realidade.

Peter Berger (1994) define realidade como "uma qualidade pertencente a fenômenos que reconhecemos terem um ser independente da nossa vontade" (Berger, 1994:11). Podemos compreendê-la, igualmente, como uma construção discursiva, já que a conhecemos a partir de discursos produzidos sobre ela. Neste ponto, discurso e representação se aproximam conceitualmente, pois compreendemos que as representações da realidade são discursos construídos sobre ela, já que estão sujeitas aos mecanismos de controle do discurso (Foucault, 1999) $)^{5}$. Ao cientista social caberia, portanto, escrutinar o processo de produção dessa "realidade", ou seja, dos discursos produzidos sobre ela.

Foucault (1999b) chama atenção a um detalhe importante na produção destes discursos quando trata da questão da representação. Na análise que faz do quadro de Velásquez, Las Meninas, Foucault conclui que nada escapa à

\footnotetext{
${ }^{4}$ Para Rorty o desejo por "validade universal" significa dizer "posso defender isso com sucesso diante de qualquer um" - uma tolice, segundo o autor. Para o filósofo, isso só é possível numa situação "em que as regras do jogo argumentativo estivessem previamente acordadas" (Rorty, 2005: 117).

${ }^{5}$ No texto em questão, Foucault trata de alguns mecanismos de controle na produção dos discursos, dos quais, neste trabalho, destacamos a "vontade de verdade". Outro dispositivo que contribui na compreensão da realidade como uma produção discursiva é a disciplina, a qual produz exigências que disciplinam o olhar e o falar sobre a realidade, sujeitando-a, assim, ao campo discursivo.
} 
representação. No quadro, os personagens olham para fora, para um ponto onde se localizam simultaneamente: 1) o modelo, que observa toda a representação mas é captado apenas tangencialmente pelo espelho; 2) o espectador, que contempla a cena; 3) o pintor, que a tudo cria. Mesmo estando do lado de fora da tela, eles estão lá dentro. São levados, seja pelo olhar dos personagens, seja pelo reflexo tangencial no espelho.

A análise de Foucault nos ajuda a refletir sobre a posição do cientista social na análise/ produção da realidade. Assim como o pintor do quadro está fora, mas é levado, ainda que tangencialmente, para dentro da representação pelos olhares dos personagens, da mesma forma o cientista social que, embora distanciado da "realidade" pelos seus métodos, está dentro dela - sua presença também é perceptível pela direção dos olhares. Semelhante é a posição que o soberano (modelo que posa) ocupa na representação. Ele está fora e, no entanto, organiza todo o quadro. É invisível, se localiza fora do quadro, porém sua realidade é projetada para dentro dele.

Dessa forma, compreendemos que no processo de criação dos discursos estão envolvidos mecanismos de controle que tratam da circulação e produção destes, mas que também existem especificidades que envolvem o papel que o próprio cientista social desempenha neste sistema, já que não é possível falar "de fora" da representação. Portanto, é importante conhecermos e analisarmos as bases, os mecanismos de produção destes discursos (científicos).

Na sua atividade, o cientista social lida constantemente com representações de sociedades e culturas. Poderíamos, talvez, dizer que estas são seu principal objeto de trabalho. Quero destacar aqui que, nessa atividade, o cientista social consome, produz e reproduz representações do outro, que, em outro momento servirão de objeto a outro cientista social, ou até mesmo à sociedade de uma forma geral. Ou seja, essas representações contribuem para a formação do imaginário social sobre aquela cultura ou sociedade. Quando um sociólogo ou antropólogo realiza uma pesquisa onde conclui, por exemplo, que brasileiro é apaixonado por futebol, esta representação criada passa a fazer parte do imaginário social, entrando na disputa pelas representações do sobre o que é ser brasileiro.

Assim, concluímos que cabe ao cientista social escrutinar os processos de produção da "realidade", assim como seus discursos concorrentes. A produção do 
discurso deve, então, ser compreendida não apenas pelo que ele diz do seu objeto, mas também quem diz, de onde diz e por que o diz.

Edward Said, no seu trabalho clássico, Orientalismo, enfatiza "que nem o termo 'Oriente' nem o conceito de 'Ocidente' têm estabilidade ontológica" (Said, 2007: 13). Dessa forma, o autor chama atenção ao fato de estes conceitos não serem um dado da natureza, mas, ao contrário, construções e, mais ainda, construções do Outro, já que, em grande medida, quem "define" o Oriente é o Ocidente, da mesma forma que quem define o "não-civilizado" é o "civilizado", ou quem define o "tradicional" é o "moderno". Said observa que nesse processo é operada uma homogeneização do Outro a partir de uma característica desqualificante, ou antes, desqualificada, desprezando suas especificidades.

Said explica que quando o termo Orientalismo é usado pode estar se referindo a três coisas diferentes, porém interdependentes: uma disciplina acadêmica; um "estilo de pensamento"; ou um discurso, no sentido de Michel Foucault. O que Said busca destacar, principalmente em relação ao terceiro ponto, é que na construção desse discurso, o Oriente deixa de ser um objeto livre de pensamento. Não que o que pode ser dito sobre o Oriente já esteja prédeterminado pelo Orientalismo, mas que este "consiste numa rede de interesses" que é acionada sempre que se discute o "Oriente" (Said, 2007: 30). Como se os termos, e em muitos casos, os valores do debate, estivessem pré-determinados. Como Kathryn Woodwart explica, "os discursos e os sistemas de representação constroem os lugares a partir dos quais os indivíduos podem falar" (Woodward, 2011: 18). Dessa forma, sempre que se fala em Oriente, todo um imaginário, construído pelo Orientalismo enquanto discurso, é acionado.

Para Said, o Orientalismo nada mais é do que um discurso produzido pelo Ocidente. Dito de outra maneira, uma definição do Oriente pela lógica ocidental. O Orientalismo, afirma Said é "uma dimensão considerável da moderna cultura político-intelectual" e, como tal, tem mais a falar sobre o próprio Ocidente do que sobre seu suposto objeto, o Oriente (Said, 2007: 41). Said prefere, então, compreender o Orientalismo como as lentes que o Ocidente escolheu usar para olhar para o seu outro. Said entende que essa escolha tem mais a dizer sobre os hábitos ocidentais do que os orientais.

Neste trabalho escolho seguir a pista de Said. Entendo que a forma como olhamos para o Outro tem mais a dizer sobre nós mesmos do que sobre o Outro, 
seja este a Ibéria, o Brasil ou os Estados Unidos. Pela negativa ou pela positiva falar do Outro também é falar de si mesmo pois, como no caso de Foucault, o pintor é puxado para dentro da tela pelos olhares dos personagens que ele próprio pinta.

\subsection{2.}

\section{Ciências Sociais e o conceito de modernidade}

No primeiro capítulo do livro O Processo Civilizador, "civilização" é definida por Norbert Elias como um conceito que "expressa a consciência que o Ocidente tem de si mesmo". Ou seja, define "o nível de sua tecnologia, a natureza de suas maneiras, o desenvolvimento de sua cultura científica ou visão de mundo, e muito mais" (Elias, 1994:23). Resume tudo aquilo que caracteriza e que é motivo de orgulho ao Ocidente. Conclui-se, assim, que o conceito de civilização foi forjado como forma de diferenciação daquilo que é ocidental - e, consequentemente civilizado - do que não é. Dessa forma, o conceito de civilização, e aquilo que é caracteristicamente ocidental, assumem pretensões universalizantes.

Contribuem com esta pretensão de universalidade duas características levantadas por Elias para o conceito de "civilização". A primeira delas é a ideia de processo. O autor afirma que "'Civilização' descreve um processo ou, pelo menos, seu resultado. Diz respeito a algo que está em movimento constante, movendo-se incessantemente 'para frente'". (Idem, 1994:24). Há implicada aí uma ideia de progresso, de que é possível civilizar-se mais. Subentende-se desta afirmação, ainda, uma hierarquia entre mais e menos civilizados.

A outra característica apontada por Elias é a de homogeneização. Segundo o autor, "o conceito de civilização minimiza as diferenças nacionais entre os povos: enfatiza o que é comum a todos os seres humanos ou - na opinião dos que o possuem - deveria sê-lo" (Idem, 1994:25). A afirmação de que deveria sê-lo impõe uma necessidade de civilizar-se. Ou seja, não apenas é possível, mais sim, necessário "civilizar-se". Considerando-se que civilizar-se, para aqueles que adotam o termo com o sentido exposto por Elias, significa adotar as mesmas instituições e padrões de comportamento que França ou Inglaterra, fica clara a ideia de homogeneização presente no conceito. 
Desta forma, a ideia de processo, aliada à característica homogeneizante do conceito de civilização, dá a este a pretensão de ser universal, servindo de justificativa moral para a disseminação do modo de ser inglês e francês como um dever ser para as demais sociedades, consideradas, assim, como atrasadas.

As ciências sociais têm utilizado de forma semelhante o conceito de modernidade, que tem sido um conceito central no estudo das sociedades, pois a partir dele, os povos e culturas têm sido divididos em dois grandes grupos: os modernos e os pré-modernos ou não modernos ${ }^{6}$. Essa distinção, realizada de forma neutra e objetiva, é, na verdade, carregada de valores. Sabemos que "a cultura é como uma lente através da qual o homem vê o mundo" (Benedict, 1972 apud Laraia, 2007:67). O aparato metodológico e espistemológico utilizado pelo pesquisador funciona de forma semelhante, refletindo a cultura, e valores, do pesquisador.

Faz parte de todo discurso hegemônico a naturalização da própria cultura e o tratamento das demais como tradições culturais. A "normalização" de uma cultura acontece quando todas as características positivas são a ela atribuídas, de forma que ela se torna o padrão, o desejável, o dever ser. Esta se torna a forma mais poderosa de hierarquização de culturas, já que a cultura "normal" é posta no fim da trajetória de "desenvolvimento". Nesta chave, as demais culturas, só podem ser negativamente avaliadas em relação a ela. Tomaz Tadeu Silva faz afirmação semelhante em relação à produção de identidades: "A identidade normal é 'natural', desejável, única. A força da identidade normal é tal que ela nem sequer é vista como uma identidade, mas simplesmente como $a$ identidade" (Silva, 2011:83). Ou seja, a forma de pensar do grupo hegemônico não é vista como uma possível, mas como a forma natural de pensar.

Retornemos ao trabalho de Elias, que analisa, além do conceito de "civilização", também o de "cultura". Este, ao invés de ser entendido como processo, é compreendido como a expressão particular de um povo. Dessa forma, igualmente diferente do conceito de civilização, este conceito delimita, define, revela as especificidades ao invés de homogeneizar (Elias, 1994:25).

Minha atenção à discussão de Elias reside não na definição dos conceitos civilização e cultura - em si, mas sim em tomá-los como duas chaves de análise

${ }^{6} \mathrm{Ou}$, em outros termos, desenvolvidos e subdesenvolvidos ou em desenvolvimento, avançados e atrasados, ou ainda, tradicionais, conservadores, entre outros temas semelhantes. 
possíveis. Assim, quando falamos em civilização, falamos de uma escala crescente ou decrescente, ou seja, falamos de uma hierarquia. Por outro lado, quando falamos de cultura, falamos em formas singulares de expressão. O conceito de civilização cobra, ainda, uma referência constante. Ou seja, se é civilizado em relação a algo. Já o conceito de cultura não cobra essa referência - é a expressão de um povo, é assim e ponto. A comparação é possível, é claro, mas ela não implica uma escala de mais ou menos qualquer coisa, apenas demonstra a diferença.

Não podemos, no entanto, ser ingênuos e pensar que quando operamos na chave da cultura as análises são "puras", ou isentas de qualquer nível de hierarquização. As identidades são construções sociais e, como tais, estão sempre em disputa, o que envolve relações de poder assimétricas. Voltaremos a este ponto mais adiante, porém, é importante destacar aqui que os conceitos de civilização e cultura, apropriados como chaves de análise, nos permitirá repensar muitos discursos produzidos sobre a Ibéria, já que grande parte deles possui a Europa (Inglaterra e França, geralmente) e Estados Unidos como sujeito-referente, como "identidade normal".

No sentido exposto acima, podemos afirmar que os estudos sobre modernidade, ou mais precisamente, sobre processos de modernização em países periféricos, têm realizado uma classificação hierárquica de culturas. Na medida em que, como já dissemos, estes conceitos são carregados de valores, classificações como, desenvolvidos/subdesenvolvidos ou adiantadas/atrasadas, implicam uma ideia de progresso, uma classificação do outro sempre em comparação com um dever ser.

Edward Said (2007) afirma que a autoridade do Ocidente é dada pela construção do Oriente. A partir do momento que as ciências sociais, nascidas nestes países centrais, classificam as demais culturas a partir do que elas não são ou não tem, é criada uma hierarquia de culturas. O mais interessante desse processo é que os povos que são classificados como atrasados e pré-modernos assumem esta forma de pensar para si próprios, ou seja, pensam suas histórias e suas culturas nestes termos classificatórios. Em seu artigo Weber $e a$ Interpretação do Brasil (1999), Werneck Vianna afirma que, no Brasil, Weber é mobilizado mais para tratar das formas patológicas de acesso ao moderno do que para identificação de patologias da modernidade, associando-se "ao diagnóstico 
que reivindica a ruptura como passo necessário para a conclusão dos processos de mudança social que levam ao moderno" (grifo no original). Essa se torna uma característica das ciências sociais nos países periféricos: a análise de sua história e cultura pelo que deveriam ser ao invés de pelo que são. No mesmo sentido, Lander afirma que "em todo mundo ex-colonial, as ciências sociais serviram mais para o estabelecimento de contrastes com a experiência histórica universal (normal) da experiência europeia (ferramentas neste sentido de identificação de carências e deficiências que têm de ser superadas), que para o conhecimento dessas sociedades a partir de suas especificidades histórico-culturais" (Lander, 2005: 36).

\section{2.}

\section{História e Representação}

Entendendo que o discurso histórico também pode ser compreendido como representação, aproximando-se do sentido de "simbolizar" ou "significar", na definição de Raymond Willians para o termo, com a "sobreposição entre o sentido [...] de tornar presente à mente e o sentido [...] de representar algo que não está presente" (Willians, 2007:353), podemos afirmar que a narrativa histórica sobre determinada sociedade, como Ibéria, Estados Unidos ou Brasil, também é uma representação desta.

Os debates acerca da representação em história dizem respeito à possibilidade, ou não, da produção de um conhecimento sobre o passado, a partir de uma disciplina específica. Francisco Calazans Falcon (2000) busca compreender a questão "história e representação" 7 , situando-a "na encruzilhada de dois percursos historiográficos", como dois olhares em direções opostas. A distinção que Falcon realiza entre estes "dois olhares" é interessante para pensarmos duas formas distintas de representação. A primeira, que chamaremos essencializada, apoia-se na existência de um referencial extra-discursivo, numa

7 Três pontos explicam a relevância do debate historiográfico para este trabalho: 1) A importância dos textos sobre o "passado" para a leitura e narração do presente; 2) A importância destes textos, ou seja, do discurso historiográfico, como produtor de representações e identidades nacionais; 3) A oportunidade de observar, no debate entre história e representação, algumas características interessantes deste conceito ao tema aqui abordado. 
essência a ser representada. A segunda, desessencializada, não cobra esse referente ${ }^{8}$.

A historiografia que estamos chamando essencializada refere-se a uma tradição intelectual fundada no Iluminismo e centrada na razão. Neste caso, a história é o conhecimento produzido sobre a História, referente extra-discursivo ou realidade histórica. A representação aqui é compreendida como "categoria inerente ao conhecimento histórico" (Idem, 2000: 42). Ou seja, nesta tradição historiográfica, o passado está lá e a função do historiador é produzir um conhecimento sobre ele. Este conhecimento será uma representação desse passado. Para demarcar distância da literatura ficcional, a história, neste caso, lida com "protocolos de verdade" (Idem, 2000: 59).

Já a historiografia que chamo desssencializada tem sua emergência histórica a partir dos anos 60 e 70, resultado do chamado linguistic turn (virada linguística), ou seja, "o encontro de diversas correntes teóricas baseadas num pressuposto comum acerca da filosofia da linguagem, isto é, da linguagem como instância constituinte da "realidade"" (Idem, 2000: 43). Neste caso, a representação sugere a "negação da possibilidade mesma desse "conhecimento"” (Idem, 2000: 42).

Essa tradição, assim como a anterior, não é homogênea. No entanto, podemos afirmar que, de uma forma geral, ela busca desconstruir, principalmente, a ideia de verdade presente na anterior. Aqui, não existe algo a dizer sobre um passado que "está lá", pois "o passado chega até nós como narrativas e são estas que constituem a 'realidade'. [...] O passado que 'conhecemos' é sempre contingente em relação a nossas concepções e a nosso presente" (Idem, 2000:60). Dessa forma, não é possível uma representação que corresponda à "verdade" do passado, pois não temos como conhecê-lo a não ser através de narrativas sobre ele. E, como estas narrativas são contingentes em relação ao historiador, "elas são infinitas e teoricamente equivalentes, embora, na prática, o poder e a ideologia tendam sempre a hierarquizá-las ou até a suprimir algumas delas" (Idem, 2000: 61). Para explicar, Falcon apresenta o conceito de world-making, de Funkenstein:

\footnotetext{
${ }^{8}$ A discussão de Falcon é interessante para mim pela distinção que o autor realiza entre duas concepções diferentes de representação, as quais denomina moderna e pós-moderna. Como não estou convencida da conveniência destes conceitos, principalmente no que se refere ao pósmodernismo, e também porque uma discussão destes fugiria ao objetivo deste trabalho, procurei redefini-las de acordo com o que entendo ser verdadeiramente relevante aqui: a identificação e uso - ou não - de essências na construção das representações.
} 
ou seja, toda narrativa sobre o passado é uma nova construção deste ${ }^{9}$ (Idem, 2000: 68 , nota 16$)$.

\subsubsection{1.}

\section{Narrativas em disputa}

Para explorar um pouco mais esse conceito de world making, destacamos três características das narrativas históricas em geral, encontradas nos trabalhos de Hayden White (2006) e Dipesh Chakrabarty (2001). São elas: 1) vestem-se de neutralidade na transmissão do fato histórico; 2) enxergam um fato histórico como um dado a ser "descoberto"; 3) possuem a Europa como sujeito-referente, isto é, são construídas a partir de um olhar europeu, mesmo quando pretendem tratar de histórias "subalternas". Os dois primeiros pontos podem ser encontrados no trabalho de White, e o terceiro, no de Chakrabarty.

Hayden White aponta três características para a narrativa histórica tradicional, das quais destacamos duas: 1) "a narrativa é considerada um container neutro do fato histórico" (White, 2006:191); 2) os eventos históricos constituemse de "um amontoado de estórias 'reais' ou 'vividas", as quais devem ter suas evidências "dispostas diante do leitor para ter sua verdade reconhecida imediata e intuitivamente" (White, 2006:192) ${ }^{10}$.

$\mathrm{Na}$ primeira característica, White critica a ideia de uma narrativa entendida como veículo neutro do fato histórico, argumentando que as técnicas de construção do enredo transformam as "estórias, como declarações factuais" em “entidades linguísticas" pertencentes à "ordem do discurso" (White, 2006:192) ${ }^{11}$. Foucault nos ajuda a compreender que estas narrativas não podem ser neutras: primeiro, porque estão imersas na sociedade; segundo porque correspondem ao discurso de uma "disciplina", a história. Segundo Foucault, a disciplina é o lugar

${ }^{9}$ O conceito de realidade de Elias guarda semelhança com essa ideia. Segundo Malerba (2000: 208-9), para este autor, realidade "é o mundo em transformação. Sua ontologia é processual, já que ela busca conhecer não o ser, mas o sendo das coisas. Nesse sentido, a realidade será sempre correlata à capacidade das sociedades humanas de conhecê-la e transformá-la". De forma semelhante, para Rorty a linguagem não é uma forma de representar o mundo, mas de agir sobre ele (Rorty, 1989 apud Pulino, 2000: 121).

10 A terceira característica apontada por White, não destacada para este trabalho, seria a utilização de linguagem ordinária, não-técnica.

11 Essa característica destacada por White está incluída entre as três "fontes de vulnerabilidade" da história, apontadas por Falcon, que são: 1) condições das "fontes"; 2) 
onde as três instâncias do poder ("relações de poder", "relações de comunicação" e "capacidades objetivas") estão ajustadas. Segundo o filósofo, o processo de disciplinarização das sociedades, a partir do século XVIII, na Europa, representou o ajuste cada vez mais racional destes três tipos de relação, isto é, "entre as atividades produtivas, as redes de comunicação e o jogo das relações de poder" (Dreyfus e Rabinow, 1995: 242). Portanto, uma narrativa construída sob essas relações não podem ser consideradas neutras.

A segunda característica remete à ideia do fato histórico como um dado a ser descoberto pelo historiador, da qual também encontramos grande referência na obra de Foucault. No texto Nietzsche, a Genealogia e a História, o autor censura a busca de origens no fazer histórico, opondo uma "história das invenções" a uma "história das "descobertas"”. Esta última estaria imbuída da crença em verdades ahistóricas. De acordo com este pensamento, existiriam fatos históricos "em si mesmos", ou seja, o fato histórico, ou a verdade, estaria lá, só restando ao historiador o trabalho de descobri-lo, ou revelá-lo ao senso comum. A primeira, a "história das invenções", ao contrário, remete à ideia de que até mesmo o fato histórico é uma construção (Foucault, 2008). Foucault posiciona-se a favor da primeira.

A "história das descobertas" seria uma busca das origens, o que significa estar em busca da verdade última das coisas. Em contrapartida, Foucault propõe a genealogia, ou uma "história genealógica", que se opõe "ao desdobramento metahistórico das significações ideais e das indefinidas teleologias”. (Idem, 2008:261). $\mathrm{Na}$ genealogia, o retorno ao acontecimento, ao passado histórico, não acontece para "traçar a lenta curva de uma evolução, mas para reencontrar as diferentes cenas em que eles desempenharam distintos papéis" (Idem, 2008:260). A história baseada na procura das origens, por outro lado, supõe um "ponto de vista suprahistórico"12 (Idem, 2008:271),

condições de produção do discurso histórico; 3) condições subjetivas do pesquisador (Falcon, 2000: 59).

${ }^{12} \mathrm{O}$ debate existente sobre a formação do Estado moderno é bem ilustrativo do ponto que estamos explorando. Tamar Herzog, no texto Identidades Modernas: Estado, Comunidade e Nação no Império Hispânico, aborda o debate sobre a existência ou não de nações no mundo hispânico pré-colombiano. Diante desse debate, a autora afirma que o mesmo está fundamentado em procurar a existência ou não de nações no passado, explicitando o anacronismo do tema. Afirma que o debate se utiliza de categorias modernas para pensar um mundo onde essas categorias não existiam. Segundo a autora, o abandono do anacronismo é possível "se abandonarmos a pergunta 'se as ações existiam no passado' e procurarmos identificar que tipo de comunidades havia no período moderno e como as pessoas se relacionavam com elas" (Herzog, 
A terceira característica da narrativa histórica, apontada acima, pode ser encontrada no trabalho de Dipesh Chakrabarty (2001). O autor afirma que a história contada tradicionalmente é sempre uma história da Europa, pois a tem como referência constante para todas as demais histórias: "Existe um caminho peculiar pelo qual todas estas outras histórias tendem a converter-se em variações de uma narrativa máster que poderia chamar-se 'a história da Europa'" (Chakrabarty, 2001:134 - livre tradução). Os historiadores dos países periféricos sentem necessidade de fazer referência aos historiadores europeus ${ }^{13}$. Estes últimos, no entanto, não sentem nada similar ${ }^{14}$.

A partir do trabalho de Falcon (2000) podemos observar duas ideias distintas para a relação entre história e representação. Na primeira, que chamamos essencializada, o papel da representação é servir como veículo neutro daquele passado para os leitores do presente. Assim, existe um passado, o passado, que será representado pelo historiador. Na segunda, desessencializada, não existe passado como um dado a ser descoberto, o que não possibilita a criação de uma representação deste. Neste caso, apenas representações são possíveis, e entende-se que, cada representação é uma narração deste passado. E estas narrativas competem entre si.

A expressão "narrativas que competem" pegamos de White, e tem a ver não com os fatos em si, ou seja, com sua "veracidade", mas em como estes são

2003:117). A partir desse novo questionamento, a autora encontra categorias que melhor expressariam a forma de identificação dessas comunidades. A questão importante para mim não é o que seria mais real, ou mais verdadeiro, mas sim que o método utilizado por Herzog permitiu a criação de um novo passado para as comunidades pré-colombianas, ao invés de enquadrá-las numa linha única de desenvolvimento histórico.

${ }^{13}$ É ilustrativa a análise de Raymundo Faoro sobre da história portuguesa. Seu trabalho é baseado na ideia da existência de um pensamento político universal, que seria o produzido por Inglaterra e França (que ele chama "Europa"). A experiência vivida por estes dois países se transforma em história "universal". O próprio autor afirma que Portugal, no período da Inquisição, "manteve-se impenetrável à ciência europeia, ao pensamento político universal" (Faoro, 1994:20). Ou seja, para Faoro, pensamento europeu é o mesmo que pensamento universal. Analisando a história por essa perspectiva, qualquer instituição que não esteja de acordo com os padrões "europeus", ao invés de ser compreendida dentro de uma lógica própria, será analisada negativamente em relação à trajetória europeia.

${ }^{14}$ Chakrabarty também faz referência às constantes "ausências" e "faltas" nas narrativas históricas do terceiro mundo (Chakrabarty, 2001:140). Esta questão das ausências, segundo o autor, vem de uma homogeneização de termos que classifica a transição do período índio para o inglês como do "medieval" para a "modernidade". Os termos mudam com o tempo: medieval foi chamado "despótico", enquanto modernidade foi chamada "império da lei". No entanto, as dicotomias, cuja mais recente talvez seja "feudal/ capitalista", permanecem (Chakrabarty, 2001:141). Estas classificações dicotômicas acabam por classificar as sociedades de forma hierárquica, pois, por mais que se tenha uma análise objetiva, estes termos são em si mesmos carregados de valores. 
relacionados e apropriados na construção da narrativa. No caso da história ibérica, por exemplo, dois autores, Raymundo Faoro (1994) e Rubem Barboza Filho (2000), trabalham com o mesmo "fato": a característica expansionista da Ibéria, ou seu "territorialismo", nos termos de Arrighi (1996). Ambos os autores, neste sentido, "olham" para a mesma coisa. Os discursos produzidos, no entanto, são completamente diferentes, pois, enquanto Faoro aponta esta característica como a marca do fracasso de Portugal e Espanha, Barboza a trata como "o diferencial ibérico". Assim, enquanto para Faoro a cultura ibérica é atrasada, para Barboza ela é uma "variante civilizacional do ocidente". Neste caso, o fato analisado é o mesmo, o que torna estas narrativas diferentes, ou "concorrentes", é o posicionamento dos autores, a apropriação que estes realizam.

Essas representações estão em constante disputa pela posição de narrativa vencedora. Nesse sentido, um dos objetivos deste trabalho é observar estes discursos em disputa pela narrativa vencedora da cultura ibérica e, consequentemente, de Brasil, pois aquelas alimentam narrativas sobre este, sobre sua trajetória política, criando outras representações, que também estão em disputa.

Estes discursos ou representações competem entre si, disputando por seus adeptos, por aqueles a quem julgam (ou querem) representar. Disputam por ser o porta-voz dessa identidade que estão construindo. Agem como se a identidade estivesse lá e eles fossem seus porta-vozes. Entendo, porém, que nesse processo, a estão construindo.

Podemos afirmar, então, que o produtor do discurso opera com uma ideia de representação essencializada, porque julga representar algo que está lá - existe um referente extra-discursivo. Aqui, como analista, também crio representações, porém opero com uma ideia de representação desessencializada, pois entendo que a identidade está sendo construída pelos discursos. Essa compreensão de narrativas em disputa só é possível atibuindo-se equivalência entre elas, abandonando a busca de discursos verdadeiros em favor de discursos justificáveis. A verdade pode ser compreendida, assim, como uma construção disputada.

Dessa forma, a compreensão de como estes discursos "competem" entre si, ou mesmo a identificação destes pontos divergentes, sob a perspectiva de que o discurso é construído e funciona como instrumento de poder, poderá enriquecer o debate. 


\section{3.}

\section{Identidade}

Entendemos que estes discursos modelam o imaginário coletivo destas sociedades, formatando, inclusive, identidades. Como estes discursos estão em constante concorrência, podemos concluir que essas identidades são construídas em meio à disputa. Os movimentos sociais ilustram o que quero apresentar aqui, na medida em que estão imersos em disputas pelas identidades que "representam" e, nesse processo, as constroem, através das identificações surgidas. Acredito que aconteça de forma semelhante no caso desses discursos sobre o Brasil, sobre a Ibéria. São identidades sendo construídas em meio a disputa e que, assim como os movimentos sociais, estão em busca de adeptos. Dessa forma, mesmo que os autores em questão neste trabalho não estejam preocupados com a construção de uma identidade brasileira, na medida em que narram, cada um a sua maneira, a cultura ibérica e a história do Brasil, criam discursos sobre estas e, assim, forjam identidades.

Kathryn Woodwart (2011) apresenta três marcas da identidade. A primeira é que a identidade é relacional. Isso significa que ela precisa do seu "outro" para existir, porque é definida por aquilo que ela não é. Disso decorre a segunda marca: a identidade é marcada pela diferença, o que não significa a inexistência de semelhanças. Ao mesmo tempo em que "a diferença é sustentada pela exclusão: se você é sérvio, você não pode ser croata, e vice-versa" (Woodwart, 2011: 09), há a afirmação da semelhança, que seria produto da história compartilhada. A terceira marca da identidade apontada pela autora são os símbolos, existindo, assim, "uma associação entre a identidade da pessoa e as coisas que uma pessoa usa" (Idem, 2011: 10).

Estas marcações são válidas tanto para identidades pessoais, quanto nacionais. E, tanto uma quanto a outra não são naturais, mas "mas são formadas e transformadas no interior da representação" (Hall, 2011:49). Podemos compreender, a partir de Hall, a cultura nacional como um discurso, dentro do qual são produzidos sentidos sobre a nação, permitindo processos de identificação e, assim, formando identidades. Esses sentidos, por sua vez, estão nas histórias e memórias que são contadas que, conectando o presente com o passado, como no 
caso dos nossos autores, criam imagens, ou representações, da nação. Segundo Benedict Anderson, a nação é uma "comunidade imaginada", e as diferenças entre as nações, são diferenças na forma como são imaginadas.

Os autores em questão neste trabalho também se utilizam desse recurso - a explicação do presente pelo passado. Essa conexão entre presente e passado, no entanto, não obedece a critérios fixos. Diferentes sentidos e memórias estão em jogo, assim como diferentes aspectos do presente e do passado estão em flutuação, sem haver um elo de ligação necessário entre eles. O produtor do discurso é quem cria esses elos, quem os conecta. Neste processo, está sujeito a, pelo menos, dois padrões: 1) o disciplinar (Foucault, 1999), no sentido da disciplina à qual pertence (que já abordamos quando apresentamos a questão da representação dentro do campo disciplinar da História); 2) o seu "ideal de boa vida" (Taylor, 1997), pois ele pode privilegiar um aspecto em detrimento do outro, ou ainda observar o mesmo, mas valorá-los de forma diferente. Voltaremos a este ponto adiante.

Woodwart também faz referência a essa volta ao passado, explicando que uma das formas de afirmação da identidade nacional "é por meio do apelo a antecedentes históricos" (Woodwart, 2011: 11). Esse retorno ao passado, no entanto, não significa "que haja algo estabelecido e fixo na construção da identidade" (Idem, 2011: 11). Pelo contrário, fala mais da nova posição que o elemento resgatado ocupa na construção da identidade presente, do que sobre ele mesmo no passado. Dessa mesma forma podemos afirmar que o que Morse e Schwartzman falam sobre a Ibéria revela mais sobre o que é ser brasileiro hoje, do que sobre a identidade ibérica do passado. Nas palavras da autora:

A reprodução desse passado, nesse ponto, sugere, entretanto, um momento de crise e não, como se poderia pensar, que haja algo estabelecido e fixo na construção da identidade sérvia. Aquilo que parece ser simplesmente um argumento sobre o passado e a reafirmação de uma verdade histórica pode nos dizer mais sobre a nova posição-de-sujeito do guerreiro do século XX que está tentando defender e afirmar o sentimento de separação e de distinção de sua identidade nacional no presente do que sobre aquele suposto passado. Assim, essa redescoberta do passado é parte do processo de construção da identidade que está ocorrendo neste exato momento e que, ao que parece, é caracterizado por conflito, contestação e uma possível crise. (Idem, 2011: 12).

Uma coisa a se pensar, neste caso, é porque aquele determinado aspecto do passado foi resgatado e não outro? O que esse momento diz sobre o presente? Sobre a identidade presente? O elemento é resgatado, às vezes, completamente fora do seu contexto "original", destituído do sentido a ele atribuído 
anteriormente. Isso porque não está sendo resgatado para falar do passado, mas para falar do presente. O resgate do passado, portanto, obedece à lógica do presente, porém não necessariamente por intenção deliberada de dolo por parte do interpretador, mas porque a moldura com a qual ele olha revela seu compromisso com o presente e impacta ou organiza seu olhar sobre o passado,

O discurso da cultura nacional, portanto, coloca lado a lado, de forma ambígua, passado e futuro, expressos numa tentação de retorno "às origens" versus um avanço para o futuro. Segundo Hall, existe um elemento regressivo na construção das identidades nacionais, e ele se expressa justamente por esse retorno ao passado, no apelo ao resgate de uma identidade perdida. Hall identifica esse elemento regressivo nos nacionalismos contemporâneos, concluindo com uma citação de Immanuel Wallerstein:

os nacionalismos do mundo moderno são a expressão ambígua [de um desejo] por [...] assimilação no universal [...] e, simultaneamente, por [...] adesão ao particular, à reinvenção das diferenças. Na verdade, trata-se de um universalismo através do particularismo e de um particularismo através do universalismo (Wallerstein, The Politics of the World Economy, 1984: 166-7 apud Hall, 2011: 58).

\subsection{1.}

\section{Três concepções de identidade}

Stuart Hall (2011) distingue três concepções de identidade, apoiadas em três concepções de sujeito: o sujeito do Iluminismo, o sujeito sociológico e o sujeito pós-moderno.

A concepção iluminista é essencialmente individualista. Parte da ideia de que o indivíduo nasce com determinadas características que serão desenvolvidas ao longo do tempo. Parte de uma "concepção da pessoa humana como um indivíduo totalmente centrado, unificado, dotado das capacidades de razão, de consciência e de ação" (Hall, 2011: 11).

O sujeito sociológico, segundo Hall, é influenciado pela complexificação da sociedade moderna. Ele ainda possui um núcleo interior - o "eu real" - mas este é formado na interação com pessoas importantes para ele. "De acordo com essa visão, que se tornou a concepção sociológica clássica da questão, a identidade é formada na 'interação' entre o eu e a sociedade" (Idem, 2011: 11) e preenche o espaço entre o interior e o exterior, "entre o mundo pessoal e o mundo público", “suturando" o indivíduo à estrutura (Idem, 2011: 12). 
O sujeito sociológico encontra correspondência entre as paisagens culturais exteriores a ele e sua própria identidade, que foi formada na interação com esse exterior. $\mathrm{O}$ argumento da crise de identidade é de que esse estado de coisas está em transformação. O sujeito está se fragmentando, assim como "as identidades, que compunham as paisagens sociais 'lá fora' [...], estão entrando em colapso, como resultado de mudanças estruturais e institucionais" (Idem, 2011: 12).

Esse processo de transformação produz o sujeito pós-moderno, "conceitualizado como não tendo uma identidade fixa, essencial ou permanente". A identidade não é mais unificada em torno de "um eu coerente", mas "torna-se uma "celebração móvel'” (Idem, 2011: 13), de acordo com a forma que somos representados nos sistemas culturais dos quais participamos.

Em resumo:

Sujeito iluminista: possui um eu unificado e sua identidade é formada através das escolhas racionais que realiza. No entanto, a "essência" desta já está dada.

Sujeito sociológico: possui um "eu real", que é modificado pelo diálogo com os mundos culturais exteriores a ele. A identidade, nesse caso, preenche o espaço vazio entre o eu e o exterior, suturando o indivíduo à estrutura social. Essa "sutura" traz estabilidade, pois gera uma correspondência entre o que "está dentro" e o que "está fora".

Sujeito pós-moderno: possui um eu fragmentado. A ideia de uma identidade unificada é dada por uma "confortadora "narrativa do eu", pois o que passa a prevalecer em seu lugar são "processos de identificação". Estes ocorrem pela maneira que somos representados e interpelados pelos sistemas culturais dos quais participamos. Tanto o indivíduo quanto as paisagens culturais estão fragmentadas. É como se diversas partes do indivíduo estivessem disponíveis, em flutuação, dentro. Fora, diversas paisagens culturais também disponíveis. A identificação ocorre quando uma parte interior encontra uma parte exterior. E estas se encontram no discurso, no que é ressaltado o papel da representação, já que a identidade não existe a priori, mas na medida em que se cria um discurso sobre ela. 


\subsection{2.}

\section{O descentramento do sujeito}

Hall também nos explica como a ideia de um sujeito com identidade centrada nasceu e como essa concepção foi tomando cores sociológicas e, agora, está sendo deslocada. $\mathrm{O}$ autor reconhece, no entanto, que esta é uma forma simplista de se contar a história, mas ela tem a fundamental utilidade de, demonstrando três diferentes concepções de sujeito, nos permitir pensar que estas concepções mudam e, portanto, tem uma história.

A afirmação de que a modernidade produziu um novo tipo de individualismo e, com ele, um novo sujeito, é lugar-comum na teoria social. Isso não significa que a época pré-moderna não possuía sujeitos, mas que a individualidade era vivida e conceitualizada de forma diferente. Os indivíduos tinham as tradições e as estruturas sociais como bases estáveis de suas identidades. Essas estruturas, compreendidas como sendo divinamente estabelecidas, não são passíveis de mudanças fundamentais e o indivíduo encontra-se a elas submetido. O processo de surgimento da modernidade destrói/ fragmenta essas estruturas e tradições, fazendo surgir o sujeito soberano.

Hall afirma, a partir de Raymond Williams, que a história do sujeito individual possui dois significados: o sujeito é "indivisível” e singular, único. Muitos movimentos no pensamento e na cultura ocidentais contribuíram para essa concepção: Reforma Protestante, Humanismo Renascentista, Revolução científica, Iluminismo. Na filosofia, Hall lembra de Descartes ${ }^{15}$ e de Locke ${ }^{16}$, que contribuíram com essa concepção de sujeito.

Esse indivíduo soberano, da razão, está inscrito nos processos de construção do mundo moderno. De acordo com Raymond Williams, a emergência de novas formas de individualidade nesse período é uma consequência do colapso da ordem medieval e, até o século XVIII ainda é possível pensar a partir desse indivíduo soberano. Conforme a sociedade vai se complexificando, no entanto, se pensa

15 Viveu o período de deslocamento de Deus do centro do Universo e resolveu esse problema colocando-o como "primeiro motor" de tudo, e explicando todo o resto em termos matemáticos e mecânicos. Para explicar um fenômeno, segundo Descartes, era preciso reduzi-lo até ao mínimo, até ao irredutível. Assim, para compreender o ser humano, chegou até sua capacidade de raciocinar, "penso, logo existo". Dessa forma, colocou o sujeito individual no centro da mente - esse é o indivíduo cartesiano. 
cada vem mais em termos sociais e coletivos - "o cidadão individual tornou-se enredado nas maquinarias burocráticas e administrativas do estado moderno" (Hall, 2011: 30).

Surge, então, uma concepção mais social do sujeito, localizado e definido no interior das estruturas da sociedade moderna. Dois movimentos contribuem para isso: o surgimento da biologia darwiniana, biologizando o indivíduo, ou seja, dando-lhe ancoragem na natureza; e o surgimento das novas ciências sociais. Estas tem um desenvolvimento desigual: o indivíduo continua soberano na economia e nas leis modernas; a psicologia torna-se a responsável pelo indivíduo e seus processos mentais; a sociologia, por sua vez, foi a responsável por explicar “como os indivíduos são formados subjetivamente através de sua participação em relações sociais mais amplas; e, inversamente, do modo como os processos e as estruturas são sustentados pelos papeis que os indivíduos neles desempenham" (Hall, 2011: 31). Essa é a concepção sociológica de indivíduo, onde há reciprocidade entre interior e exterior.

O sujeito sociológico, segundo Hall, é um produto da primeira metade do século XX. No entanto, no mesmo momento, está surgindo um movimento que apresentava uma visão menos harmoniosa da individualidade - o Modernismo, que traz imagens proféticas do que iria acontecer com o sujeito cartesiano e o sujeito sociológico na modernidade tardia.

Hall prossegue afirmando que aqueles que postulam a ideia de identidade moderna fragmentada, apontam a ocorrência não apenas de numa desagregação, mas de num deslocamento através de "rupturas nos discursos do conhecimento moderno" (Hall, 2011: 34). Dessa forma, o autor aponta cinco avanços na teoria social que tiveram impacto sobre o "deslocamento do sujeito".

Tradição do pensamento marxista. Na releitura feita nos anos 60 da obra de Marx, a partir da famosa frase "homens fazem a história, mas apenas sob as condições que lhe são dadas", Althusser afirma que Marx rejeita qualquer essência do homem como base teórica, causando uma ruptura nos postulados da filosofia moderna.

Inconsciente de Freud. A ideia de que nossa identidade, sexualidade e estrutura de desejos obedecem a uma lógica diferente daquela da Razão desloca a

${ }^{16}$ Locke define o indivíduo em temos de "mesmidade de um ser racional", ou seja, a identidade da pessoa permaneceria a mesma. 
identidade fixa e unificada de Descartes. Segundo Lacan, a criança não se vê como uma entidade unificada, senão apenas pelo olhar do outro, na "fase do espelho". A formação da identidade, que se dá com a rejeição de partes de si, inconscientemente, acompanha o sujeito por toda a vida. No entanto, "ele vivencia sua própria identidade como se ela estivesse reunida e 'resolvida' [...] como resultado da fantasia de si mesmo como uma 'pessoa' unificada” (Hall, 2011: 38). A identidade permanece incompleta, em formação, e sempre há algo de "imaginário" quanto a sua unidade. Hall sugere que, ao invés de tratar da identidade como algo fechado, pronto, deveríamos falar em identificação: "A identidade surge [...] de uma falta de inteireza que é 'preenchida' a partir de nosso exterior, pelas formas através das quais nós imaginamos ser vistos por outros" (Hall, 2011: 39). A representação que fazem de nós contribui, ou melhor, é parte integrante de nossa identidade.

Estruturalismo linguísico - Saussure. Não somos os "autores" do que afirmamos porque a língua é um sistema social, não individual. Nenhum indivíduo detém o significado último do que expressa. Quando nos comunicamos, acessamos códigos e sentidos do sistema linguístico e cultural do qual fazemos parte. Os significados não são fixos; surgem na relação com os objetos e as outras palavras, no que reside sua analogia com a identidade: sei quem sou "eu" em relação ao "outro". A analogia continua: "O significado é inerentemente instável: ele procura o fechamento (a identidade), mas ele é constantemente perturbado (pela diferença)" ( Idem, 2011: 41).

Michel Foucault. Foucault realiza em seus trabalhos uma genealogia do sujeito moderno, onde destaca um novo tipo de poder - o "poder disciplinar", que, embora resultado de "novas instituições coletivas e de grande escala da modernidade tardia, suas técnicas envolvem uma aplicação do poder e do saber que 'individualiza' ainda mais o sujeito" (Idem, 2011: 43). Dessa forma, é possível concluir que "quanto mais coletiva e organizada a natureza das instituições da modernidade tardia, maior o isolamento, a vigilância e a individualização do sujeito individual" (Idem, 2011: 44).

Impacto do feminismo. O movimento feminista surge na década de 60 do século XX, momento em que surgem os novos movimentos sociais, que têm, dentre outras características a de apelar para a identidade de seus sustentadores: movimento sexual - lésbicas e gays; movimento racial - negros; movimento 
feminista - mulheres, o que "constitui o nascimento histórico do que veio a ser conhecido como a política de identidade - uma identidade para cada movimento" (Idem, 2011: 45). Tanto quanto movimento teórico quanto como movimento social, o feminismo contribuiu para o deslocamento do sujeito cartesiano por questionar a distinção entre "público" e "privado", abrindo à contestação política áreas antes restritas ao pessoal, como família e sexualidade, por exemplo. Também politizou a subjetividade (mãe/ pai, homem/ mulher).

Dessa forma, Hall demonstra os movimentos teóricos que contribuíram para o descentramento do sujeito, tendo como produto o que chamou de sujeito pósmoderno.

\subsection{3.}

\section{Considerações finais}

Como podemos observar, a representação que fazem de nós é parte integrante de nossa identidade. Assim, os discursos sobre a Ibéria, ou mais especificamente sobre o Brasil, conformam o que é o Brasil. Foucault complexifica a questão ao afirmar que estes discursos estão em competição, sujeitos a jogos de poder, ou seja, estão em disputa.

A questão de nossa identidade ser "alimentada" pela imagem que fazem de nós, ou pela sua representação, nos remete à importância da alteridade, pois igual importância tem a nossa representação do outro - aquele que não sou eu, meu diferente. Nesse sentido, poderíamos dizer que a identidade é aquilo que eu sou, enquanto a diferença aquilo que o outro é. Essa afirmativa, porém, pode ser problematizada, pois a identidade não é o oposto da diferença. Pelo contrário, são dependentes.

No artigo A produção social da identidade e da diferença, Tomaz Tadeu Silva explica que a identidade e a diferença são dependentes porque na afirmação de uma identidade (por exemplo, "sou brasileiro") contém uma "extensa cadeia de 'negações', de expressões negativas de identidade, de diferenças": "não sou chinês", "não sou argentino", "não sou italiano" etc. (Silva, 2011: 75). Essa dependência, no entanto, está oculta na forma como afirmamos a identidade "sou brasileiro". 
A diferença, em geral, é vista como produto da identidade. Nessa perspectiva, a identidade se torna a referência, reforçando a tendência de considerarmos as coisas a partir do nosso ponto de vista. O autor, por sua vez, coloca na origem a diferença, entendida aqui como "processo de diferenciação". Essa compreensão desloca o centro de definição da "identidade" para um "processo", o de diferenciação, do qual tanto a identidade quanto a diferença são resultados.

Entendemos que tanto a diferença quanto a identidade são socialmente produzidas, mas não convivem harmoniosamente. São, ao contrário, disputadas. As classificações envolvidas nas questões da identidade participam dessa disputa. Dentre as classificações possíveis, uma das que possuem mais força são os binarismos, como por exemplo, a separação entre "nós" e "eles". Segundo Woodwart, "nesses dualismos um dos termos é sempre valorizado mais que o outro: um é a norma e o outro é o 'outro' - visto como 'desviante ou de fora'” (Woodward, 2011: 51-2).

Neste capítulo foram abordados os conceitos centrais de todo o trabalho. Entendo que as identidades são construídas e as representações que dela fazem participam dessa construção. O debate entre Simon Schwartzman e Richard Morse é compreendido sob essa perspectiva. Morse, no livro que se torna o pivô do debate, apresenta um painel histórico das bases civilizacionais do Ocidente, e, nesse movimento, cria uma representação da cultura que narra. Da mesma forma, Schwartzman, quando critica o livro em questão, também cria uma representação dessa cultura. Essas representações engendram identidades, que estão em constante disputa. No capítulo que se segue, apresento essas narrativas. 


\section{3}

\section{O debate entre Morse e Shwartzman}

\section{1.}

\section{Introdução}

É comum observarmos no pensamento social brasileiro a referência à cultura ibérica como um caminho para explicar nossa própria constituição social, política e cultural ${ }^{17}$. Olhando para Portugal e Espanha (mais para o primeiro, no caso do Brasil), poderíamos compreender nossa própria trajetória, interpretada como um reflexo da cultura de nossos antigos colonizadores. Dessa forma, compreendendo a trajetória política de Portugal, suas instituições e sua cultura, compreenderíamos a nós mesmos.

A difícil tarefa de se pensar o Brasil pode ser feita por diferentes caminhos. A referência aos nossos ex-colonizadores e a uma "herança ibérica", além de ser apenas um dentre outros caminhos possíveis, não é de forma alguma um caminho natural. Pelo contrário, a escolha desse caminho (e não outro) é resultado de opções teórico-metodológicas feitas pelo pesquisador e de uma forma determinada de entendimento de como os processos sociais ocorrem.

Dessa forma, as representações das sociedades ibéricas, Portugal e Espanha, mostram-se relevantes no contexto do pensamento político e social brasileiro, na medida em que elas servem de pano de fundo para as representações do próprio Brasil. Podemos notar a importância desse debate, por exemplo, quando Octavio Ianni, procurando delinear "as linhas de pensamento ou mesmo as 'famílias' de explicações do Brasil" (Ianni, 2004: 68), mobiliza a tradição ibérica, em duas das cinco linhas de pensamento levantadas, como elemento explicativo ${ }^{18}$. Outra

${ }^{17}$ Essa referência é observada nas ex-colônias da América do Sul de uma forma geral, tanto de origem espanhola quanto portuguesa. Esse trabalho, no entanto, se restringirá ao caso brasileiro.

${ }^{18}$ Nestas linhas de pensamento, nas quais a tradição ibérica é mobilizada, Ianni ressalta um elemento de mistura, entre o "português" e o "brasileiro", utilizando o termo "lusotropical". No entanto, sem maiores explicações para este conceito, transmite a ideia de que essa "herança", essa mistura, seja algo dado. 
referência possível é o trabalho de Sérgio Buarque de Holanda que, em Raízes do Brasil, por exemplo, dá como primeira característica da nossa formação cultural o fato de sermos uma civilização ao mesmo tempo portuguesa e brasileira, ressaltando, ao longo do trabalho as consequências (às vezes positiva, outras negativa) dessa herança.

Um exemplo já clássico dessa mobilização da tradição ibérica para explicação do Brasil pode ser encontrado nos trabalhos de Raymundo Faoro - Os Donos do Poder e Existe um Pensamento Político Brasileiro?. Nestes trabalhos, o autor se detém bastante na história portuguesa, tratando, inclusive, da formação do Estado português, como forma de explicar a formação política do Brasil.

A tradição ibérica foi tema central, também, de importantes trabalhos mais recentes do pensamento político, dos quais destaco Tradição e Artifício Iberismo e barroco na formação americana, de Rubem Barboza Filho. O objetivo do autor neste livro é desenvolver a tese da Ibéria como "variante civilizacional do Ocidente", cuja opção política foi pelo territorialismo, em detrimento do capitalismo, ambos compreendidos como lógicas de desenvolvimento distintas.

Teríamos ainda muitos outros exemplos possíveis: Gilberto Freyre, Roberto DaMatta, Tavares Bastos, Oliveira Vianna, autores que mobilizam, de alguma forma, a cultura ou tradição ibérica na explicação do Brasil. Toda essa mobilização, como já era de se esperar, guarda uma multiplicidade de representações da Ibéria: ora representada como uma tradição "pré-moderna", "atrasada", como um peso de passado sobre as costas do jovem Brasil, evocando a necessidade de ruptura para que se alcance a "modernidade"; ora classificada como um ponto positivo, garantidor de uma especificidade latino-americana que serviria como contraponto aos modelos europeu e norte-americano. De qualquer forma, o debate gerado em torno dessa tradição demonstra o cenário de disputa existente sobre a representação de Brasil, disputa que se dá a partir destes discursos criados. Dessa forma, entendemos que a compreensão destes discursos pela perspectiva da competição, buscando a identificação destes pontos divergentes, será uma contribuição ao debate.

Neste capítulo, pretendo observar como essas construções ocorrem através do debate que acontece entre Richard Morse e Simon Schwartzman por ocasião da publicação do livro $O$ Espelho de Próspero, pelo primeiro, seguida de um artigo- 
crítica pelo segundo. O debate conta ainda com mais dois artigos, um de cada autor $^{19}$.

No livro, publicado originalmente em 1988, Morse defende a ideia de que as Américas, ibérica e anglo-saxã, partem de um mesmo tronco civilizacional - o Ocidente que, em determinado momento histórico, realizam opções políticas distintas. Por isso, conclui que a América Ibérica não pode ser compreendida como um projeto de civilização frustrado, mas como uma civilização em si mesma $^{20}$. Para Morse, os ideais civilizacionais que inspiraram o Norte estão esgotados e o autor identifica na cultura ibérica uma fonte onde estes podem ser renovados. Sugere, então, que talvez tenha chegado a hora de mostrar o espelho ${ }^{21}$, que tem sido insistentemente mostrado ao Sul, ao Norte, confrontando com ele a experiência histórica da América ibérica, "não mais como estudo de um caso de desenvolvimento frustrado, mas como a vivência de uma opção cultural" (Morse, 1988: 14).

O "debate" tem início com a publicação do artigo-crítica de Schwartzman, O Espelho de Morse, em outubro de 1988, onde o autor argumenta contra as ideias expostas no livro, das quais a "mais danosa" seria a apresentação da América Ibérica como espelho para a América Anglo-Saxã, o "canto da sereia da contemplação estética dos nossos umbigos" (Schwartzman, 1988: 192) ao qual não podemos sucumbir.

Em resposta, Morse publica, em 1989, um artigo intitulado A Miopia de Schwartzman, onde procura responder às críticas, a partir da identificação de três diferenças fundamentais com seu crítico: compreensão quanto à natureza do processo histórico, quanto à forma como se dá o conhecimento e quanto à facilidade para identificar heróis e vilões na história. Schwartzman insiste no debate publicando O Gato de Cortázar, também em 1989, dividindo sua argumentação em quatro partes: uma refutação geral ao artigo de Morse, uma resposta à acusação de positivista e empirista, uma explicação sobre porque

\footnotetext{
${ }^{19}$ Os artigos foram publicados na revista Novos Estudos CEBRAP, entre outubro de 1988 e outubro de 1989, cujas referências completas encontram-se ao final do trabalho.

${ }^{20}$ Rubem Barboza Filho, no livro Tradição e Artifício, desenvolve essa tese de Morse.

${ }^{21}$ A Ibero-América é tratada como uma imagem refletida no espelho no qual a AngloAmérica se olha. E ali pode reconhecer suas mazelas e vislumbrar alguma alternativa. $\mathrm{O}$ espelho mostra a imagem refletida de forma invertida. E isso ocorre com as Américas que, apesar das mesmas fontes civilizacionais, tem trajetórias opostas.
} 
considera que alguns países são mais atrasados que outros e uma explicação de porque pode considerar algumas ideias perigosas.

O debate, portanto, é muito rico em temas e conteúdo. Meu interesse nele é observar como é construída e representada a identidade ibérica nestes autores, a partir da identificação de dois eixos principais. Primeiro, como os autores representam e classificam valorativamente a "tradição cultural ibérica". Segundo, observar a compreensão que eles têm do trabalho intelectual e do papel da ciência. A identificação destes dois eixos nos ajudarão a construir, mais adiante, uma reflexão sobre dois projetos políticos distintos de sociedade.

Quando se propõe a investigar as "famílias intelectuais" do Brasil, Gildo Marçal Brandão (2005) põe o foco de sua análise nas "formas de pensar subjacentes", que define como "estruturas intelectuais e categorias teóricas, a partir das quais a realidade é percebida, a experiência prática elaborada e a ação política organizada (Brandão, 2005: 236-7). Entendo que essa "moldura" do olhar sobre a realidade é formada pelas "categorias teóricas" que o analista utiliza, mas também pelos valores dos quais partilha, ou, nas palavras de Taylor (1997), pelo seu ideal de boa vida. Com isso em mente, passemos aos autores.

\section{2.}

\section{O pivô do debate: $O$ Espelho de Próspero}

Morse inicia seu livro deixando clara sua visão sobre as Américas do Sul: pretende tratá-las "não como vítima, paciente ou 'problema', mas como uma imagem especular na qual a Anglo-América poderá reconhecer as suas próprias enfermidades e os seus 'problemas"” (Morse, 1988: 13 - grifo no original). Ou seja, sua abordagem da Ibero-América (termo que prefere à América Latina) será como uma alternativa civilizacional aos padrões, já esgotados, da Anglo-América. Nesse sentido, utiliza a metáfora do espelho, cuja inspiração vem de El mirador de Próspero (1909), de José Enrique Rodó. No entanto, enquanto para este o mirador era uma torre de observação e Próspero um mestre, para Morse, Próspero são os Estados Unidos, e o mirador, um espelho. Segundo o autor, este espelho (anglo-saxão) tem sido mostrado de forma insistente ao Sul. O que Morse sugere, no entanto, é que talvez tenha chegado o momento de "virar esse espelho" e confrontar ao norte a experiência histórica da América ibérica, "não mais como 
estudo de um caso de desenvolvimento frustrado, mas como a vivência de uma opção cultural" (Idem, p. 14).

O livro é dividido em três partes: Pré-história, onde trata das origens europeias das Américas; História, que aborda as Américas no período pósindependência e À sombra do porvir, onde Morse mostra sua visão do futuro do Ocidente e apresenta a Ibéria como uma alternativa civilizacional. A parte do livro intitulada "Pré-História" procura resgatar um passado geralmente esquecido nas comparações entre as Américas, ou seja, sua "pré-história" europeia, datada entre os séculos XII e XVII, período de consolidação de algumas tendências (como, Estados Nacionais, diversificação religiosa, desenvolvimento capitalista) importantes para a compreensão de suas respectivas visões de mundo. Esse retorno à "pré-história" empreendido por Morse busca "compreender que as respectivas tradições surgem de uma matriz moral, intelectual e espiritual comum" (Idem, p. 22) e que, a partir dessa matriz, entre os séculos XII e XVII foram feitas opções que definiriam os "diferentes padrões" do que Morse chama de "civilização ocidental".

Morse identifica duas versões da história ocidental em curso, uma angloamericana outra ibero-americana. Na primeira, a história do Ocidente, é comumente relatada como um crescendo, cuja compreensão atual afirma seu início com "a explosão capitalista-científica", originada "por imperativos morais e religiosos", mas que, adquirindo impulso próprio, "há dois séculos pelo menos, vem corroendo esses imperativos originais" (Idem, p. 27). Ao lado desta, expõe outra história, que tem como características principais a escolástica, a moral greco-romana, a doutrina cristã, entre outras. Esta, diferente da outra, não possui características evolutivas. De acordo com Morse, esta

"apresenta a história moderna como uma nota de rodapé, e não como a apoteose, das escolhas espirituais feitas no período formativo. Em termos freudianos, é a história não do organismo biológico submetido a leis imutáveis de crescimento e decadência, nem da pessoa pública avaliada segundo padrões de carreira e realizações, e sim da psique interior, revelada em súbitos clarões espontâneos e arcaicos, mas sujeita a um processo cumulativo de racionalização, repressão e sublimação" (Idem, p. 28).

A explanação desta segunda história, a história Ibero-Americana, é o objetivo do autor. A apresentação que Morse faz destas "duas histórias", ou mesmo a identificação de ambas, já depõe sobre a compreensão que o autor possui 
do que seja o processo histórico, ou de como ele funcione, e também sobre sua compreensão dos valores que alimentam essas trajetórias. A explanação de Morse mostra uma Anglo-América pautada em ideais de progresso que se mostram esgotados, enquanto, por outro lado, nos apresenta uma Ibero-América pautada sobre ideais de organicidade, cujo processo histórico não se baseia no ideal de progresso, mas em expressões de originalidade.

Morse realiza esse retorno à pré-história europeia das Américas para mostrar sua origem comum, que, segundo o autor, foi marcada pelas revoluções religiosa e científica. Dessa forma, sua explicação neste tópico segue dois movimentos: primeiro, explicar a situação histórica e filosófica anterior a essas revoluções; segundo, explicar as distintas opções políticas que Espanha e Inglaterra tomaram diante dessas revoluções.

Morse aponta dois resultados importantes dessas revoluções. Primeiro, o surgimento "de uma 'ciência' cada vez mais compartimentada e uma 'filosofia' cada vez mais desencarnada" (Idem, p. 28), pela infantilização e posterior abandono das "indagações epistemológicas profundas" dos primeiros escolásticos. Morse destaca que ingleses e espanhóis passaram por essas revoluções, porém, seus posicionamentos diante delas foram diferentes. Enquanto os ingleses mergulharam no "moderno", os ibéricos foram mais cautelosos: "acompanharam as questões-chave durante o final da Idade Média e então, no umbral da modernidade, mantiveram suas posições" (Idem, p. 29), ou, mais ainda, retrocederam aos padrões anteriores a elas. Este posicionamento é tratado por Morse como uma escolha política justificada racionalmente pela tradição filosófica e teológica pela qual a tradição ibérica é marcada, destacando três filósofos que resumiriam o pensamento cristão desse período: Pedro Abelardo, Aristóteles e Tomás de Aquino.

Para tentar compreender melhor o posicionamento ibérico, espanhol, distinto do inglês, diante das revoluções científica e religiosa, Morse explica dois pontos. Primeiro que, no período, a responsabilidade de eleição de objetivos comuns na Espanha pertencia ao Estado, forjado por uma intelectualidade católica. Dessa forma, não era estranho à sociedade viver sob princípios que, baseados na teologia, emanavam de um poder central. Situação que se contrasta com a inglesa, onde a responsabilidade pela eleição de objetivos comuns, retirada do Estado, fora atribuída “a um mercado supostamente 'livre' de ideias e 
prescrições privadas, agora tratadas como "mercadorias"” (Idem, p. 38). Podemos identificar no pensamento de Morse, neste ponto, que o autor identifica tanto na Espanha, quanto na Inglaterra, a existência de um "princípio regulador", sendo que na primeira este é exercido pelo Estado, enquanto na segunda, pelo mercado.

O segundo ponto diz respeito a que na Espanha do século XVI havia um consenso geral sobre a natureza do governo - "suas fontes de legitimidade, o alcance exato de seu poder, sua responsabilidade de assegurar justiça e equidade, sua missão 'civilizadora' em face dos povos não cristãos de seu território e de ultramar" (Idem, p. 39), oferecendo um cenário em que "as alternativas políticas eram buscadas dentro de uma matriz de interesses teológicos, morais e filosóficos" (Idem, p. 39). Esses dois pontos explicam como, ou porquê, num cenário onde a Espanha estava exposta às influências das revoluções religiosa e científica, estas eram sempre "orquestradas dentro de uma matriz ideológica que [...] favorecia mais a necessidade nacional e social, tal como era percebida, do que as aventuras intelectuais privadas" (Idem, p. 40).

Morse explica que no momento em que as revoluções religiosa e científica tornam-se sensíveis, a Ibéria já possuía uma visão de mundo moderna estabelecida, fundamentada na autoridade divina e eclesiástica, o que a tornou resistente a elas. Rubem Barboza Filho, sobre este trecho do livro de Morse, explica que as revoluções científica e religiosa provocaram a reação contrária da Igreja, mas esta não se deu por recusa ao método científico experimental simplesmente, mas por recusa à crença na infalibilidade da razão advinda deste que, por sua vez, colocava em xeque a autoridade da Igreja. Assim, a Ibéria permanece num "curso autóctone e não meramente defensivo" (Barboza Filho, 2000: 95) em relação ao restante da Europa, no que se refere às revoluções científica e religiosa em curso. Segundo Morse, os reis espanhóis do século XVI podiam optar entre duas tradições: medieval e renascentista. Na primeira, o sujeito político é identificado não como indivíduo, mas pela sua localização social e missão cristã. O governante, por sua vez, é obrigado moralmente a impor as leis de Deus. Já a tradição do Renascimento encontra sua fonte no maquiavelismo amoral. Morse identifica os reis Isabel, de Castela, e Fernando, de Aragão, com representantes das tradições renascentista e medieval, respectivamente. 
De acordo com Morse, do período imediatamente após a morte de Isabel até ao reinado de Carlos V estas opções estavam em equilíbrio, até que com Felipe II acontece o momento da escolha, que Morse chama de

preferência 'tomista' por uma sociedade concebida como uma casa de muitos níveis e salas, uma entidade cujas partes estavam ordenadas como o imperfeito em relação ao perfeito e onde as tarefas de ordenamento e adjudicação, ainda que firmadas em primeira instância por consenso popular, recaíam sobre o rei, atuando em nome de seus súditos como o agente melhor colocado e apto para a função (Morse, 1988: 55).

O que o autor procura demonstrar com este debate é que não se trata de "persistência por inércia" ou de uma "invocação recorrente da escolástica" ao longo dos séculos, mas sim que, no momento das viagens ultramarinas as sociedades ibérica e anglo-saxã "adotaram, deixaram-se levar ou foram arrastadas" por dois conjuntos de premissas políticas que orientam a lógica da ação e da reflexão política até hoje. Essas formulações, geradas num momento crítico da história, conformaram "dois conjuntos de imperativos institucionais, econômicos e morais" distintos (Idem, p. 56).

Assim, as opções políticas dessas sociedades não são mostradas por Morse de forma determinística, nem como sendo estáticas no tempo. Pelo contrário, estão em constante diálogo com formulações teóricas internas e externas a essas sociedades, mas que, ainda assim, como orientadas por lógicas distintas de pensamento, resultam em diferentes opções políticas.

Enquanto o edifício inglês passa por uma reformulação no século XVII, a Ibéria não passa por nenhuma reordenação radical. Diante das mudanças ocorridas no mundo a monarquia barroca espanhola parece decidir como central a "questão da conservação e o problema político de como conservar o Estado" (Idem, p. 67). Centrado no Estado, o pensamento político na Espanha barroca compreendia a liberdade não como os limites de imunidade para o indivíduo, mas como a obediência voluntária ao poder constituído. Morse destaca, dessa forma, o papel do Estado como corolário da liberdade, com a função de manter a ordem e a justiça.

Na segunda parte do livro, intitulada "História", Morse volta seu olhar para as colônias americanas até o momento das revoluções de independência. Segundo o autor, essas colônias partilhavam da cultura política de suas metrópoles de tal forma, que torna-se quase impossível distinguir estruturas coloniais de 
metropolitanas, dada a integração entre elas. No entanto, a partir do século XVIII, a caminho dos seus processos de independência, essas nações enfrentam dois grandes desafios: "o caráter aparentemente inadequado de sua tradição política e a natureza incoerente de sua organização social" (Idem: 72). Isso porque, como já foi explicado, a Ibéria não acompanhou as opções feitas pelo Norte. E, se no século XVII a Ibéria ainda propunha ideais alternativos, no XVIII isso se torna impossível, pois ela se torna uma "consumidora intelectual".

Segundo Morse, o período de Ilustração ibérica, de uma forma geral, costuma estar associado ao termo "ecletismo" que, em sentido mais estrito, "indica abstenção da especulação sistêmica e tentativa de resolver problemas práticos" (Idem: 73). Essa preocupação com problemas práticos, no pensamento ilustrado ibérico, é somada às premissas anteriores, voltando-se cada vez mais para resolver problemas do capitalismo e do Estado nacional. Na ausência de uma situação "revolucionária", os significados anteriores dessas premissas não foram reexaminados, perdendo, assim, sua capacidade doutrinal e sua relevância para resolução de problemas práticos. Dessa forma, o que se observa no pensamento ilustrado ibérico, é uma tentativa de harmonização da nova racionalidade com a tradição, dando-lhe a aparência de um mosaico, e não um sistema.

Segundo Morse, o que hoje interpretamos, retrospectivamente, como um processo de integração com o sistema econômico mundial, para os contemporâneos soava como "um processo de desarticulação" - o ideal ibérico entrando em colapso, abrindo espaço para a dicotomização da sociedade.

O período transicional para a independência vivido pelas sociedades iberoamericanas foi marcado pelo abandono dos ideais neo-escolásticos por argumentos de fontes anglo-francesas. Esse abandono, no entanto, ocorreu, segundo o autor, apenas no plano intelectual - a expressão política informal continuou sendo pautada pela tradição neo-escolástica. A questão que se coloca para esse período, segundo Morse, não é a dúvida dos intelectuais entre as visões de mundo ibérica e anglo-francesa, mas sim que não existia uma combinação passível de aceitação.

Essa necessidade de "combinação" encontra uma explicação mais aprofundada na tese de Rubem Barboza Filho sobre o barroco americano. Segundo o autor, este barroco não é como o europeu, formado pela reafirmação da tradição, 
mas forma de vida e ambiente criados pelo trágico encontro de raças e povos arrancados de suas origens, obrigados a liquidar a coerência de seus sistemas e significados metafísicos para conviverem e sobreviverem numa imensidão hostil (Barboza Filho, 2000: 15).

Dessa forma, o barroco americano, nesse período em que as identidades dessas nações começam a ser forjadas, encaminhando-se para o processo de independência, se utilizará da visão de mundo anglo-francesa como um material sempre disponível à incorporação de acordo com a vontade política, sem ocorrer, no entanto, uma absorção completa das práticas dessas sociedades. Nas palavras de Barboza:

A forma específica de autoconstrução da América Ibérica reside nesta aparente arbitrariedade com que vive e vincula o seu passado aos produtos ideológicos do mundo moderno e contemporâneo, fazendo-se permanentemente insubmissa aos códigos proclamados como universais pela Europa ou pelo mundo anglo-saxão (Barboza Filho, 2000: 15).

O liberalismo é um exemplo disso, pois, se na Anglo-América a relação entre democracia e liberalismo resultou na dialética liberdade-ordem, na IberoAmérica, estes dois foram assimilados de forma independente e intermitente, resultando numa relação entre cálculo do poder e bem comum, entre política como arte ou ciência e Estado como incorporativo ou tutelar.

$\mathrm{Na}$ última parte do livro, “À sombra do porvir”, Morse deixa clara sua forma de análise, quando afirma que não está interessado nas formas de dominação externas: "ditadores, oligarcas, tecnocratas, capitalistas, machos, brancos e países industrializados" (Idem: 117), mas nas formas de dominação interna, da qual os agentes acima mencionados seriam apenas sintomas. A essa dominação interna Morse parece se referir à forma de pensar, às "crenças fundamentais acerca da sociedade e do governo" (Idem: 117) presentes nas mentes coletivas. A persistência desse tipo de dominação "se baseia na ilusão da 'liberdade' humana" (Idem: 117). Neste ponto, Morse parece identificar que os sistemas de pensamento funcionam como um sistema de dominação poderoso, pois mantém a ideia de uma falsa liberdade de ação ${ }^{22}$.

\footnotetext{
${ }^{22}$ Segundo Foucault, diferente da mera violência, sujeição ou opressão, a relação de poder mantém o outro como sujeito da ação. Ao invés de a ação ser determinada, como na relação de violência, ela é como que sugerida. A relação de violência mostra ao sujeito submetido que ele foi vencido e que há um novo "senhor". A relação de poder, ao contrário, mantém a ideia de que o sujeito é independente, de que é "livre" para fazer suas escolhas. Ele continua como sujeito de ação, mas como que condicionado a certas atitudes e não outras (Rabinow \& Dreyffus, 1995).
} 
Segundo o autor, esses sistemas de pensamento se referenciam aos ideais modernizantes hoje em decadência. Recorrendo à teoria crítica da Escola de Frankfut, e mais especificamente a Adorno e Horkheimer, o autor identifica uma pseudo-individualidade, completamente fragmentada entre o privado e o público, entre intimidade e imagem pública. Essa situação é resultado de "irônicas reversões na trajetória do liberalismo", que retirando a dimensão metafísica da personalidade, submeteu-a aos interesses privados, assegurando "uma harmonia unânime com as autodefinições dos outros". Toda transcendência, assim, é transferida "às grandes forças econômicas e sociais da época" (Idem: 123).

Esse, segundo a Escola de Frankfurt, é o Grande Desígnio Ocidental. Em relação à Ibero-América, o ponto é como ou o quanto podemos suportar ou enobrecer tal "Desígnio". A questão de culturas autóctones não é exclusividade da Ibero-América, mas aqui, diferente do Japão ou da Rússia, por exemplo, ela sempre foi vista como obsoleta, não como autóctone. Morse acredita que "a IberoAmérica tem sua própria cultura, que em realidade é mais profundamente ocidental que a dos países do Norte" (Idem: 128). O que precisamos, diz Morse, é captar a "realidade" atual e "vê-la não como um arcaísmo, uma mescla fortuita ou um embrião, mas como uma 'coisa em si ${ }^{23, "}$ (Idem: 129).

A penetração do Desígnio Ocidental na Ibero-América é inquestionável, não, porém, com plena racionalização da vida, sendo racionalização entendida como o vínculo que pode ser estabelecido entre razão e a noção de racionalização, apontando para o "desencantamento do mundo", de Weber. A racionalização, nesse sentido, "impregna a vida inteira da sociedade que a hospeda. Vincula pessoa com coisas e normas de conduta, de modo que entre si não fazem outra coisa senão 'relacionar-se'; a confiança é depositada no 'sistema' e não mais nas pessoas" (Idem: 132). Essa razão, ou racionalidade, não foi internalizada completamente pela Ibero-América. E isso porque

o mundo ibérico rejeitou as implicações últimas das revoluções religiosa e científica e, portanto, não pode experimentar plenamente seus resultados lógicos na forma do utilitarismo e seu subordinado individualismo, que estão implantados como marca-passos na mente coletiva do resto do Ocidente (Idem: 134).

\footnotetext{
${ }^{23}$ Rubem Barboza Filho toma esse ponto como sua tese em Tradição e Artifício: Barroco e iberismo na Formação Americana (2000), expondo-a à página 101 do livro: a Ibéria se constituiu como variante civilizacional do Ocidente, tendo o territorialismo como sua característica básica, pois dele derivam suas opções de desenvolvimento: espaço sobre o tempo, permanência sobre mudança.
} 
Morse afirma que, em comparação aos anglo-americanos, a Ibero-América sempre alimenta visões alternativas, que o leva a apresentar nosso primeiro paradoxo: o pluralismo. O paradoxo reside em que, ainda que os Estados Unidos gozem da fama de viver uma democracia pluralista, enquanto os ibero-americanos seriam inclinados a regimes autoritários, considerando a conjuntura política, os ibero-americanos seriam mais pluralistas, porque mais abertos a alternativas. $\mathrm{O}$ discurso político americano seria apoiado num único conjunto de proposições, em geral, pequenas variações do liberalismo burguês.

O segundo paradoxo apresentado por Morse diz respeito à estrutura do caráter, no que diz respeito ao liberalismo-protestante ser mais adequado para o mundo industrial do que o iberismo, católico. De acordo com o autor, qualquer ibero-americano possui uma visão macro de sua sociedade, o que seria impensável para um anglo-americano. O paradoxo atual reside em que a estrutura de caráter auto-contido do Novo Ocidente trouxe uma limitação ao campo de visão social do indivíduo, que só consegue olhar para si mesmo: "as pessoas já não 'compõem' um sistema, simplesmente 'fazem funcionar' o sistema em benefício próprio" (Idem: 145). A principal diferença é que nas sociedades ibero-americanas as pessoas percebem os sistemas de poder como exteriores a si, enquanto os angloamericanos, obedecendo apenas a regras auto-impostas, não percebem "o regime consensual e auto-imposto da eficiência administrativa" (Idem: 149) como dominação.

De acordo com Morse, a Ibero-América vem se culpando indevidamente por sua recepção indevida, às vezes incompleta ou malfeita, da sua "incapacidade de transformar os paradigmas intelectuais do Novo Ocidente em novas sínteses culturalmente "autênticas"” (Idem: 156). Segundo o autor, neste ponto reside o paradoxo final:

que o encontro agonístico do Velho e do Novo Ocidente na Ibero-América ao longo dos séculos pode conter um elemento dialético, ao passo que a lucreciana reunião fortuita de dados e interesses particulares que forma a 'opinião' numa democracia liberal exemplifica melhor a coexistência de elementos inertes (Idem: 157).

Morse conclui o livro afirmando que, num momento onde os ideais que alimentaram as sociedades ocidentais parecem ter chegado a um momento de esgotamento, o pluralismo e a visão de todo, características da tradição ibérica, surgem como alternativa civilizacional ao Norte. 


\section{3.}

\section{A crítica: O Espelho de Morse}

Por ocasião da publicação de $O$ Espelho de Próspero, por Morse, Simon Schwartzman publica um artigo-crítica. De acordo com Schwartzman, a tese do livro é que "a América Ibérica está desfocada porque ela se contempla no espelho da próspera América inglesa e, na busca inútil da imitação do outro, perde sua própria essência” (Schwartzman, 1988: 185). Isso porque, de acordo com Morse, os ideais do Norte - "liberalismo, a democracia representativa, o racionalismo, o empirismo científico, o pragmatismo" - além de estarem esgotados no Norte, são incompatíveis com os ideais da América Ibérica. Para Morse, seria na contemplação do próprio mundo latino, ou seja, da própria tradição ibérica - com sua visão abrangente e unificadora do mundo e a crença numa realidade social que transcende o indivíduo, "que se poderia encontrar uma resposta adequada à crise moral e existencial do mundo anglo-saxão, e, por reflexo, da América Latina" (Idem, p. 186).

De acordo com Schwartzman, a mensagem de Morse é sedutora, pois, da posição de fracasso, somos elevados à condição de "resposta" aos problemas do mundo anglo-saxão. No entanto, além de sedutor, "se trata de um livro profundamente equivocado e potencialmente danoso em suas implicações" (Idem, p. 186). De acordo com Schwartzman, Morse faz suas afirmações independentemente de "toda evidência empírica" mostrar o contrário. De acordo com o autor, Morse não se importa com o empírico: "que é o empírico, afinal, senão o aspecto mais superficial da realidade [...]?”, ironiza.

Nesta crítica de Schwartzman fica claro como os autores operam com distintas "formas de pensar subjacentes" (Brandão, 2005: 236). O autor afirma que Morse despreza a empiria, valorizando, ao invés dos resultados, os princípios organizacionais de cada sociedade e, por isso, afirma que o autor não esconde sua preferência por uma sociedade "arquitetônica e hierarquizada", que, precedendo aos indivíduos, lhes daria pertencimento e identidade, em oposição "às alienações e ao vazio" das sociedades industrializadas do Norte, cujos ideais encontram-se esgotados, para o autor. Schwartzman associa "arquitetônica e hierarquizada" às sociedades totalitárias, chamando atenção de que, mesmo diante do nazismo, do 
stalinismo e do regime franquista, Morse não coloca em dúvida sua "nostalgia pela totalidade e pelo transcendente" (Schwartzman, 1988: 187).

Os autores concordam que, após a independência das colônias iberoamericanas, uma crise se instaura, pois elas têm que lidar com as influências que lhes chegam do Norte: liberalismo, democracia política e marxismo. As novas nações da América ibérica incorporam ideias e mecanismos do liberalismo, mas não como valores e fundamentos éticos. Discordam, no entanto, na explicação das dificuldades para essa incorporação. Enquanto Schwartzman aponta razões de ordem política e econômica, para Morse elas são de ordem cultural.

Schwartzman chama atenção à "ausência de uma reflexão mais aprofundada", no trabalho de Morse, sobre algumas contradições do nosso desenvolvimento, dentre as quais, a tensão entre Igreja e Estado. Schwartzman afirma que as tentativas de reação ao Estado clerical são interpretadas através da antinomia "reações frustradas" versus "desejo de um retorno a uma sociedade integral”, para a qual Morse contribui. A dificuldade em fugir disso, segundo Schwartzman, é não ver a Europa continental como uma alternativa além dos Estados Unidos, que, segundo o autor, é muito mais mobilizada que este último. Nesta crítica fica evidente outro ponto fundamental de divergência quanto à tradição ibérica. Schwartzman parece ter a necessidade de buscar referência no Norte, sejam os Estados Unidos, seja a Europa, enquanto Morse insiste em analisá-la como "uma coisa em si” (Morse, 1988: 129).

Segundo Edgardo Lander (2005), a atitude de Schwartzman é uma característica das ciências sociais nos países que tiveram uma história de colonização exploradora:

em todo mundo ex-colonial, as ciências sociais serviram mais para o estabelecimento de contrastes com a experiência histórica universal (normal) da experiência europeia (ferramentas neste sentido de identificação de carências e deficiências que têm de ser superadas), que para o conhecimento dessas sociedades a partir de suas especificidades histórico-culturais (Lander, 2005: 36).

Em seu artigo "Weber e a Interpretação do Brasil”, Werneck Vianna afirma, de forma semelhante, que, no Brasil, Weber é mobilizado mais para tratar das formas patológicas de acesso ao moderno do que para identificação de patologias da modernidade, associando-se "ao diagnóstico que reivindica a ruptura como passo necessário para a conclusão dos processos de mudança social que levam ao moderno" (Vianna, 1999: 2). 
Um exemplo de um clássico do pensamento político brasileiro, que também opera com essa ideia de linearidade, é Raymundo Faoro. O livro Existe um pensamento político brasileiro?(1994) é bastante ilustrativo nesse sentido. Uma breve explanação de três dos seus capítulos, chamando atenção aos seus títulos, pode nos ajudar a refletir sobre o assunto.

Em “A Revolução Irrealizada”, segundo capítulo do livro, Faoro inicia sua análise da história portuguesa. O autor identifica nos antecedentes da Revolução de Avis aspectos que resultariam numa revolução burguesa, entretanto, "tudo se frustraria" (Faoro, 1994: 18). O autor identifica uma "precocidade" no "Renascimento" e na "supremacia burguesa" (Idem, p. 16) em Portugal. O Renascimento, segundo ele, foi "débil", pois não conseguiu romper com o "tradicionalismo político" (Idem, p. 19). A supremacia burguesa, ao invés de gerar uma "Revolução Burguesa", financiou os novos descobrimentos. O terceiro capítulo do livro, "O Reino Cadaveroso", explica como o reino português se isolou do restante da Europa, ou seja, do "pensamento político universal” (Idem, p. 20), devido às suas escolhas políticas. Assim, Faoro procura demonstrar que Portugal manteve-se preso ao medievalismo, ao tradicionalismo, enquanto a "Europa" avançava no humanismo e nas teorias "modernas" de secularização da política. O quarto capítulo, “A Ruptura Pombalina”, narra o que Faoro chama de o "reencontro de Portugal com a Europa" (Idem, p. 24). Este "reencontro" seria proporcionado pelas reformas modernizantes realizadas pelo marquês de Pombal, que tinham o objetivo de "engastar Portugal na Europa, da qual se distanciara, sem comprometer o absolutismo, a autoridade e o sistema colonial” (Idem, p. 26).

Análises como as de Schwartzman e Faoro se diferenciam bastante de outras, como de Morse e Rubem Barboza Filho, não apenas porque um fala de atraso e ruptura, enquanto os outros falam de alternativa e singularidade, mas também porque operam a partir de "formas de pensar" distintas, ou ainda, falam a partir de diferentes categorias teóricas. Neste caso, por exemplo, podemos observar que os autores possuem diferentes compreensões de processo histórico. Mesmo sem entrar em análises mais profundas neste tema, podemos perceber que Faoro e Schwartzman concebem uma linearidade na história que não é possível observar nas narrativas de Morse e Barboza. No enquadramento realizado pelos primeiros, os eventos possuem hora certa para acontecerem, enquanto nos últimos não percebemos nada semelhante. 
Voltando ao artigo de Schwartzman, a última crítica dirigida a Morse é o tratamento que este dá aos intelectuais do Sul. Para Schwartzman, Morse considera que os intelectuais da América ibérica não passam de imitadores das universidades do Norte. O foco da crítica não é nem a cópia em si, mas sim a imitação de um método decadente - a pesquisa acadêmica. Assim, nas palavras de Schwartzman, para Morse "só aos poetas, romancistas e artistas restaria a tarefa de expressar seu mundo "como centro e não como periferia"' (Schwartzman, 1988: 190).

Schwartzman conclui o artigo reconhecendo que as sociedades ocidentais enfrentam problemas graves vinculados "ao esgotamento dos valores evolucionistas do iluminismo, ao crescimento descontrolado do conhecimento como técnica e à cultura de massas" (Idem, p. 191). No entanto, estas sociedades "ainda preservam um repertório de criatividade, pluralismo e capacidade de compromisso moral e ético" bem distante do "provincianismo e corporativismo" da América ibérica. Schwartzman entende que a América anglo-saxã já alcançou "algumas conquistas” das quais nós "não chegamos nem perto" (Idem, p. 191).

\section{4.}

\section{A réplica: A Miopia de Schwartzman}

Morse escreve este artigo em resposta à crítica de Schwartzman, e o publica no mesmo periódico que seu crítico publicara. Morse inicia o texto demonstrando as preferências que tem em comum com Schwartzman, o que não impede que possuam "discordâncias fundamentais no que diz respeito ao empreendimento intelectual" (Morse, 1989: 166) e, dessa forma, contribui para que este artigo seja o mais fértil em demonstrar meu segundo ponto de destaque: a divergência entre os autores sobre qual seja a natureza, ou missão, do trabalho intelectual e o papel da ciência ${ }^{24}$. Morse identifica três diferenças principais: quanto à natureza do

\footnotetext{
${ }^{24}$ Também poderíamos incluir como diferença entre os autores, nesse sentido, suas formas de análise, ou melhor, a diferença entre o que consideram relevante nessa análise: Morse está atento às questões de ordem cultural, enquanto Schwartzman estaria às de ordem políticoeconômicas. Lúcia Lippi já ressaltara este ponto: "Podemos dizer que as explicações para o dilema da Ibero-América estariam diferenciadas: para Morse, persistência de padrões culturais; para Simon, impedimentos de ordem política configurados no padrão contraditório da colonização que perduram até hoje" (Oliveira, 2000: 11).
} 
processo histórico, quanto à forma como se dá o conhecimento e quanto à naturalização em identificar heróis e vilões na história.

Segundo Morse, essas diferenças fundamentais são de esclarecimento necessário porque "meu crítico não se limita, como fazem outros, a exigir que eu esclareça significados e interpretações distintas" (Idem, p. 169), mas, ao contrário, Morse tem a sensação de ter interferido num "monólogo interior" que o toca apenas tangencialmente, monólogo este que está diretamente relacionado à segunda diferença fundamental apontada pelo autor: a crença de Schwartzman na capacidade técnica e científica, através da academia, para resolução dos problemas sociais. Segundo Morse, Schwartzman deposita toda sua confiança na forma acadêmica de conhecimento, valorizando o conhecimento verificável, criando uma hierarquia que vai do conhecimento duro (ciência) ao conhecimento mole (arte). Nesse sentido, o livro de Morse lhe soa completamente subversivo porque, diferente daquele, este autor não vê relação direta entre o desenvolvimento das universidades e o desenvolvimento intelectual, científico ou econômico. Vem daí o desencanto do autor com a Academia americana: um distanciamento entre vida acadêmica e vida intelectual, além do modo insatisfatório como a América Latina vem por eles sendo estudada. Nesse sentido, responde às críticas quanto ao uso da literatura, afirmando que sua utilização não se designa a justificar "construções mágicas", como o acusa seu crítico, mas sim para reconstruir uma ponte de diálogo com e sobre a sociedade que Morse não acredita ser possível através do diálogo acadêmico. Para o autor, o trabalho acadêmico perdeu a criatividade e, com isso, a capacidade interpretativa a sociedade.

De acordo com Morse, Schwartzman o acusa de entoar o "canto da sereia da contemplação estética de nossos umbigos", quando sua intenção no Espelho era fazer "um grande painel" com a história dos três continentes, ajudando, assim, "a identificar a problemática da América Latina e dessa forma fornecer um objeto apropriado para contemplação" (Idem: 174). Sua suposição é a de que, considerando a América Latina como uma civilização em si mesma, conseguiremos um melhor diagnóstico na comparação com sua civilização parente: o Ocidente industrial.

Para o autor, diante de duas civilizações complexas, a questão que se coloca é a seguinte: "como deverá a América Latina reconhecer ou inventar os tipos de 
balizas de navegação ideológica para o século XXI que a Europa formulou para os séculos XVI ao XX?" (Idem: 174). Morse inverte a posição histórica clássica: transfere para a América Latina uma responsabilidade sempre atribuída ao "Norte". Nesse sentido, responde a outra crítica de Schwartzman ao afirmar que não está interessado em "exagerar" na decadência e racionalização do Ocidente, mas que sua mensagem é "que já é hora de a América Latina caminhar sem muletas" (Idem: 174).

Morse aponta sua questão central: qual a lição da Europa para a América Latina? A Europa viveu duas Reformas importantes: a Protestante e a Proletária, fruto de raízes culturais e aspirações populares. Os Estados Unidos, colonizados por emigrantes dessas Reformas, internalizaram e domesticaram seus ideais. A América Latina, por outro lado, resistiu. Espanha e Portugal barraram a entrada da Reforma Protestante, enquanto a Proletária adentrou timidamente a América Latina, devido a sua incipiente industrialização. Dessa forma, apesar de os intelectuais latino-americanos estarem acompanhando a Europa, em dia com o Romantismo e o Positivismo, foram impedidos de formar movimentos populares que "poderiam ter dado inspiração, definição e sustentação às críticas mais contundentes da intelligentsia" (Idem: 175). A América Latina não realizou nem digeriu as Revoluções europeias mas, de acordo com Morse, terá de o fazer no próximo século. No entanto, não serão como na sua forma original, pois a América Latina é uma civilização específica.

\section{5.}

\section{A tréplica: $O$ Gato de Cortázar}

O último artigo do "debate" é escrito por Schwartzman, que demonstra uma preocupação com a possível incompatibilidade entre uma agenda de modernização e as "tradições culturais latino-americanas". O autor, neste artigo, passa a tratar os argumentos de Morse como referidos à área cultural e argumenta contra o uso equivocado do que chama a "questão cultural". Segundo Schwartzman, a "questão cultural", num primeiro momento, envolveu especulações sobre "caráter nacional" e "identidade nacional", levantando a questão sobre "a capacidade de determinadas sociedades em incorporar de maneira adequada as instituições e valores das sociedades ocidentais" (Schwartzman, 1989: 191). Num segundo 
momento surge o questionamento dos próprios valores e instituições ocidentais. Hoje, a redescoberta da "questão cultural" traz o perigo do "etnocentrismo às avessas", que começa com a valorização das diferenças, mas pode terminar na afirmação de que não há sentido em que os países latino-americanos se modernizem e sejam democráticos, "dada sua tradição e cultura autoritárias" (Idem: 192).

Segundo Schwartzman, Morse discute tradição e modernidade quando se pergunta sobre os eventuais substitutos das Revoluções Religiosa e Operária na América Latina. Schwartzman concorda com Morse de que os ideais dessas revoluções não foram assimilados em territórios latino-americanos. No entanto, observa que esses ideais encontram-se esgotados também na Europa, concordando que esse esgotamento não é um problema latino-americano, mas "universal". A discordância com Morse, nesse sentido, é em relação à resposta que ele oferece: “a volta a uma 'verdadeira comunidade' perdida nas penumbras do passado - e com a forma em que ele justifica essa resposta” (Idem: 192).

Schwartzman afirma que nada no artigo de Morse responde a sua crítica principal, ou seja, "tentativa de buscar, em um utópico passado Ibérico, as fontes para uma civilização latino-americana que mostraria sua profunda superioridade em relação ao Ocidente em decadência" (Idem: 192). Segundo o autor, sua discordância com Morse não deve ser confundida com uma incapacidade de perceber o que ocorre na esfera da cultura. Ele concorda que a cultura deve ser considerada pelas ciências sociais no tratamento das questões contemporâneas. Devemos, no entanto, livrá-la da

penumbra das 'tradições culturais' qualitativamente irredutíveis entre si, e aceitemos que os fenômenos de identificação, integração coletiva e referenciais éticos podem mudar com grande velocidade, por mecanismos que seguramente não conhecemos bem, mas que estão sem dúvida associados a certos momentos de transição histórica mais significativos (Idem: 193).

Na segunda parte do texto, Schwartzman diz que Morse o caricaturou como um "empirista primitivo e empedernido", que não consegue dar lugar para a literatura e nada além do conhecimento verificável, com medo do povo, um racionalista, crente no poder dos PhD's para resolução dos problemas sociais. $\mathrm{O}$ autor diz que Morse é tão maniqueísta no trato da América Latina quanto o é em relação à atividade intelectual de uma forma geral. Segundo Schwartzman, Morse vê a sociedade dividida entre as elites aliadas aos cientistas sociais "que nos 
traíram", de um lado, e uma América Latina autêntica, de outro. Sociedade essa cujo sentido, segundo Morse, escaparia aos intelectuais que só conseguem pensar no curto prazo.

Schwartzman levanta a possibilidade de a "visão dogmática e simplificada" que Morse tem da América Latina decorra da função que ele atribui ao trabalho intelectual: "a elaboração de uma ideologia capaz de sacudir e mobilizar o continente latino-americano, e daí, quem sabe, o mundo" (Idem: 195). Como exemplo, cita a função que Morse atribui aos novelistas de "ajudar a renovar o discurso de uma ideologia obsoleta", nas palavras do próprio Morse. Para Schwartzman, desmistificar ideologias é uma das funções das ciências sociais e conclui que "a falsa polarização entre 'novelistas' e ‘cientistas sociais' que Morse introduz só pode produzir efeitos no mundo restrito dos círculos acadêmicos de elite, para consumo dos quais, afinal, ela parece ter sido feita" (Idem: 196),

Schwartzman finaliza o texto aproximando a situação da América Latina atual da Alemanha do pré-guerra, não por uma ameaça eminente de nazismo, mas por condições sociais semelhantes, entre as quais uma batalha perdida para a modernidade e a invasão de nossas universidades pelo anti-intelectualismo e pelo antirracionalismo. Afirma que as ideias de Morse não guardam nenhuma originalidade, citando um autor alemão da República de Weimar, Troeltsch, para demonstrar que estes sentimentos de "crítica ao positivismo e ao establishment universitário" (Idem: 199) e a busca por uma atividade intelectual mais rica e abrangente, já existiam naquele período. Segundo o autor, essa batalha foi travada no século passado e "hoje já conhecemos bastante bem tanto as limitações do positivismo e academicismo ingênuos quanto onde podem chegar os delírios do intuicionismo e do vitalismo" (Idem: 198). Por isso, conclui ressaltando a importância de "não esquecer os equívocos do passado, e não voltar a embarcar neles com tanta facilidade e gosto" (Idem: 203).

\section{6.}

\section{Conclusão}

Desencanto. É dessa posição que ambos os autores falam. Desencantados com suas próprias sociedades buscam no outro uma alternativa civilizacional e cultural e, nesse movimento, desprezam suas sociedades de origem. Para Morse, 
os Estados Unidos encontram-se numa situação de esgotamento dos seus ideais civilizacionais e encontra no seu outro, a Ibero-América, a alternativa. Para Schwartzman, a América Latina tem sido sinônimo de obscurantismo e autoritarismo e, igualmente, encontra no seu outro, os Estados Unidos e a Europa, sua alternativa.

Morse inicia seu livro propondo a inversão do espelho que tem sido insistentemente mostrado à América-Ibérica e percebemos, neste debate, que os autores manipulam esse espelho, cada um a sua maneira, de forma a alcançar sua própria "imagem ideal" ali refletida. Os autores, no entanto, não reconhecem que fazem uso político desse espelho, acusando-se mutuamente de defenderem predileções pessoais ${ }^{25}$.

As "lentes" com as quais Morse e Schwartzman operam já têm sido analisadas no pensamento político brasileiro há algum tempo. Lúcia Lippi (2000) toma esse debate como "atualização do confronto entre iberistas e americanistas" (Oliveira, 2000: 8). Iberistas versus americanistas tem sido uma das formas de organizar a produção das representações do Brasil. De um lado, autores que valorizam a tradição ibérica, interpretando-a, geralmente, como um diferencial diante dos ideais ocidentais modernos. De outro, autores que entendem essa tradição como um sinal de atraso, com a qual é necessária uma ruptura a fim de se alcançar o moderno.

Lúcia Lippi fala de "atualização do confronto" porque, de maneira alguma, esse debate nasce com Morse e Schwartzman. Werneck Vianna, que escreveu um texto clássico sobre o tema, traz esse mesmo debate através de outros autores: Oliveira Vianna (1883-1951) e Tavares Bastos (1839-1875). Poderíamos, igualmente, contrapor as análises Raymundo Faoro e Rubem Barboza Filho. Meu interesse aqui não é buscar o início desse debate, tampouco delinear essas famílias, classificando seus respectivos autores, o que já foi bastante e muito bem realizado no pensamento político brasileiro. Meu interesse é tomar este "confronto" como base para refletir sobre três pontos principais.

O primeiro ponto se subdivide em dois. Partindo da ideia de que os sujeitos e as identidades são construções sociais, produzidas no embate, gostaria de

\footnotetext{
${ }^{25}$ No primeiro artigo de Schwartzman, este acusa Morse de não esconder sua preferência por uma sociedade "arquitetônica e hierarquizada" (Schwartzman, 1988: 187). Igualmente Morse,
} 
observar: 1) que os pesquisadores, no nosso caso Morse e Schwartzman, também são sujeitos construídos e, assim, estão imersos em relações de poder e refletem um "ideal de boa vida" e, dessa forma, 2) as identidades por eles representadas também refletirão um pano de fundo moral. O segundo ponto é observar que este pano de fundo moral distinto pode estar apoiado em distintas concepções de sujeito.

O objetivo, em tudo isso, está longe de ser chegar a uma conclusão do que seria essa "identidade brasileira", mas observar estes discursos em disputa e, através da disputa, inclusive por sua própria existência, compreender um pouco mais sobre nós mesmos.

em sua resposta à crítica de Schwartzman, fala da predileção deste por uma "tecnoburocracia modernizante" (Morse, 1989: 173). 


\section{Sujeitos em construção, representações em disputa.}

No capítulo anterior, foi apresentado o objeto de análise deste trabalho. Neste, pretendo, retomando conceitos apresentados no primeiro capítulo, analisar alguns pontos expostos no segundo, a fim de observar como nossos autores constroem suas representações da cultura ibérica. Partindo da ideia de que os sujeitos e as identidades são construções sociais, busco analisar as diferentes formas de olhar dos nossos autores.

\section{1. \\ Sujeitos construídos}

Butler (1998) identifica nas teorias políticas dois posicionamentos no que se refere à questão do sujeito. Na primeira, associada ao pós-modernismo ou ao pósestruturalismo, a "crítica do sujeito" parece significar a negação e/ou a decretação da morte deste. Na segunda (a qual a autora não associa a nenhuma "tradição" específica), o sujeito aparece como um pressuposto da política, o que Butler classificará como um "estratagema autoritário", pois essa pressuposição impede que este termo esteja em disputa. Butler se opõe, portanto, a um sujeito pressuposto, ressaltando que essa recusa não significa negá-lo, mas sim pensar sua construção. Não pensar o sujeito como construído, nesse sentido, é colocá-lo como anterior à política, ou seja, anterior às relações de poder e, dessa forma, não condicionado por elas, ou ainda, imune a elas.

O fato de entender o sujeito como uma construção interfere em como Butler entende a tomada de posição por parte desse sujeito. Segundo a autora, o sujeito não "escolhe" sua posição, ou não "muda de posição", simplesmente, pois ele próprio é constituído por elas. Isso não significa, no entanto, que não haja escolhas, mas sim que “o 'eu’ que seleciona entre elas já está sempre constituído por elas". Esta conclusão aponta para outra, a de que "nenhum sujeito é seu 
próprio ponto de partida" (Idem, 1998:18), pois, assim como é constituído por suas posições, o sujeito também é fruto de outras ações instituídas anteriormente, tanto por ele mesmo quanto por outros. Dessa forma, suas ações também aparecem como fruto de ações anteriores, apontando para o caráter de imprevisibilidade da ação humana, que, assim, não é compreendida como fruto de um processo linear, mas como uma resultante de um feixe de relações. O sujeito, dessa forma, aparece como fruto de uma genealogia que some quando ele se torna a origem da sua ação.

Butler aborda o tema do sujeito nos termos de uma genealogia, pois pretende a suspensão de todo entendimento do que a palavra significa, para ver "as funções linguísticas a que ele serve na consolidação e ocultamento da autoridade" (Butler, 1998:24). Esta compreensão é semelhante à de Foucault que, em contrapartida a um tipo de história, ou de teoria social, que está em busca da verdade última das coisas, propõe a genealogia, que se opõe "ao desdobramento metaistórico das significações ideais e das indefinidas teleologias" (Foucault, 2008:261), propondo o retorno ao acontecimento, ou ao conceito, "para reencontrar as diferentes cenas em que eles desempenharam distintos papéis" (Foucault, 2008:260). Em ambos os casos, o termo é compreendido sob a perspectiva da disputa - seu significado não é dado, ele se transforma no tempo e no espaço. Assim, partindo da compreensão foucaultiana, podemos entender o sujeito pressuposto de Butler como algo (um conceito, uma identidade, uma representação) que se fecha à disputa, que já é dado, enquanto a abordagem genealógica operaria com a ideia de que este sujeito está em construção.

Butler explica, ainda, que o sujeito é constituído, mas não determinado. Ele possui capacidade de agir, que "é sempre e somente uma prerrogativa política" (Butler, 1998:22). Essa capacidade, no entanto, não pode ser presumida, pois ela é fruto do caráter constituído do sujeito. Ou seja, dependendo das ações que o condicionaram, suas ações podem ser direcionadas para um lado, ou para o lado oposto. Por tudo isso, Butler afirma que pressupor o sujeito é colocá-lo acima da política, pois é através dessas relações, dessas lutas de posição e conflitos de poder que ele é formado.

A forma como Butler expõe a questão nos leva a refletir sobre o caráter de "construção" do próprio pesquisador. Ou seja, sabemos que as identidades e representações são construídas socialmente, imersas em relações de poder, sempre 
em disputa pela narrativa vencedora (ou com mais adeptos). O que Butler nos traz à reflexão é a possibilidade de pensarmos que, além das narrativas, o próprio pesquisador, digamos, o enunciador do discurso (e não apenas o discurso) está imerso nessas disputas. Ora, como a autora diz, se o sujeito é constituído pelas próprias posições que assume, se pensarmos quais "posições" tem sido constitutivas de nossos autores poderemos ver novas possibilidades interpretativas surgirem.

Outro autor que pode enriquecer nossa reflexão acerca do caráter constituído do sujeito é Charles Taylor (1997), para o qual há uma relação direta entre identidade e moralidade. O filósofo afirma, assim como Butler, que o indivíduo não parte de si mesmo, aprofundando a compreensão disso com a explicação de que cada pessoa possui um horizonte moral a partir do qual ele reflete e avalia, aos outros e a si mesmo. Analisando o que chama as fontes do self no mundo moderno, Charles Taylor reconhece uma dupla composição. O self ontológico, que aponta para as características invariáveis do ser humano, e cuja interpretação sugere condições "não contingentes", isto é, desprendidos de "um momento histórico e cultural peculiar" (Mattos, 2005:40). O autor, no entanto, valoriza o que chama de self histórico, que está "ligado a uma visão particular de bem e de boa vida" (Mattos, 2005:40). Essas duas perspectivas de entendimento da construção do self, estão, segundo o autor, sob tensão na interpretação dos sujeitos modernos. A ideia de Taylor é que sempre existirá um pano de fundo moral a orientar as escolhas humanas.

Quando define a ação humana, Taylor faz uma diferenciação entre duas formas de desejo: avaliação fraca, que considera os resultados da ação; e a avaliação forte, onde a motivação para a ação é considerada. As avaliações fortes levam em consideração, portanto, uma concepção de bem, enquanto nas fracas, para que algo seja julgado bom, basta ser desejado. Assim, as ações humanas devem ser avaliadas sob o ponto de vista de que quando o ser humano decide fazer algo, ele realiza um cálculo entre estas duas dimensões do desejo das ações. Então, podemos afirmar que todo posicionamento envolve uma dimensão moral.

O ponto desenvolvido nos ajuda a refletir que, além de imerso em relações de poder e constituído pelas posições que assume, este sujeito não se posiciona em um meio opaco, ou neutro, mas sim num ambiente moral. Esse ponto é relevante, como abordaremos melhor adiante, porque, devido às exigências de neutralidade $\mathrm{e}$ 
objetividade próprias da prática científica, tendemos a lidar com a moralidade como uma "variável" de menor relevância que pode, e na maioria das vezes deve, ser desprezada. Este posicionamento, além de uma análise menos rica, tem a profunda implicação política de se distanciar das relações que põem em jogo o poder e o desejo (Foucault, 1999).

O trabalho de Taylor nos remete, portanto, à existência de "uma hierarquia moral objetiva e pré-reflexiva que serve como pano de fundo para os indivíduos pensarem, agirem e julgarem uns aos outros, bem como a si mesmos" (Mattos, 2005:49). Dessa forma, podemos compreender que os sujeitos são constituídos por valores e, assim, da mesma forma que Butler afirma que o sujeito não "escolhe" simplesmente suas posições, Taylor nos dá a entender, como afirma sua comentadora, que nossas “avaliações não são 'escolhidas', na medida em que são articulações do que já consideramos como valioso" (Mattos, 2005:44).

Um dos três pontos principais da antropologia filosófica tayloriana é a definição do ser humano como animal que se auto-interpreta. Para o filósofo, o "processo de compreensão do outro envolve, obrigatoriamente, uma comparação com a minha visão de mundo. Só é possível a partir dela" (Mattos, 2005:42 - nota 5). Quando olho para o outro não olho livremente, olho a partir da minha própria concepção do que é a vida, do que é o humano. Dessa forma, quando eu compreendo o outro minha compreensão a respeito de mim mesmo é alterada.

Esse é um ponto central para a organização de tudo que tem sido desenvolvido até aqui. Se quando olho para o outro o faço a partir da minha visão de mundo, daquilo que considero relevante, logo a representação que faço do outro fala tanto, ou mais, sobre mim mesmo do que sobre o representado. Esse é o enquadramento dado por este trabalho às representações da Ibéria. Morse e Schwartzman quando olham para a tradição/ cultura ibérica, o fazem a partir de sua própria visão de mundo. Como sujeitos constituídos que são, olham para o mundo a partir dos valores que possuem, e estes "representam escolhas em relação a uma forma de vida que é tomada como superior" (Mattos, 2005:45). Assim, as representações que fazem falam mais sobre eles próprios do que sobre a "Ibéria". 


\subsection{1.}

\section{O sujeito que pesquisa}

As ciências sociais, que lidam com análises e representações da sociedade, possuem uma especificidade que não existe em outras áreas científicas. Enquanto nas ciências naturais a distância entre objeto e pesquisador já está dada, pois são de "naturezas" distintas, nas ciências humanas ou sociais, não existe essa distância e, ainda, outros complicadores.

De acordo com Butler, as consequências da ação não se prendem à intenção do sujeito, mas a suplantam. Da mesma forma, as ações do sujeito são resultados, ainda que não intencionais, das ações de outros sujeitos. Dessa forma, o constructo social aparece como um conjunto de relações, onde uma interfere nas outras, sendo o resultado imprevisível. E esse feixe de relações ainda acontece sobre um pano de fundo moral, conforme explica Taylor, que por sua vez é formado pelos sujeitos, ao mesmo tempo em que o formam.

Essa complexidade já havia sido percebida por Max Weber. Na sociologia por ele desenvolvida, vamos encontrar uma preocupação constante com a questão da objetividade nas ciências sociais, devido justamente a esta especificidade. De acordo com Aron (1982), a ação científica, em Weber, é uma mistura da ação racional com relação a um objetivo com a ação racional com relação a um valor ${ }^{26}$. Isto porque é uma ação voltada para um objetivo - a obtenção da verdade - que, por sua vez, é orientado por um valor - a própria verdade.

A questão dos valores está sempre presente na teoria da ciência de Weber, pois, para o autor, eles participam não apenas do objetivo da ciência, mas também da delimitação do objeto. O discurso histórico, por exemplo, aparece como uma descrição seletiva do passado, porque o observador já está orientado por seus valores quando escolhe selecionar um fato e não outro, ou quando escolhe estudar um tema e não outro ${ }^{27}$.

${ }^{26}$ Weber distingue entre quatro tipos de ação social: a) ação racional com relação a um objetivo; b) ação racional com relação a um valor; c) ação afetiva ou emocional; d) ação tradicional. Weber tem como traço característico do mundo contemporâneo a crescente racionalização. Dessa forma, o processo de modernização, da forma como é compreendido pelo autor, leva à ampliação da esfera das ações do primeiro tipo.

27 A preocupação de Weber é como, diante dessas especificidades, conceder às ciências históricas e sociais o status de uma ciência positiva e racional que, em seu entendimento, possui três características principais: é sempre superável, ou seja, não existe um ponto onde tudo já foi conhecido ou estudado; é objetiva, que quer dizer que possui validade para todos que procuram 
Weber prossegue sobre a relação observador-objeto, afirmando que para compreender o sentido que os homens lhe atribuem, é necessária uma aproximação do objeto. No entanto, é igualmente necessário um distanciamento para que seja possível encontrar respostas universalmente válidas. Segundo o autor, é impossível a realização de uma análise puramente objetiva, ou seja, despida totalmente dos valores do observador. Dessa forma, cria o conceito de tipo ideal como um instrumento na mediação entre a objetividade de uma análise científica e os valores inerentes ao pesquisador (Weber, 2005).

A reflexão sobre a teoria da ciência de Weber se insere neste debate devido à sua relevância no imaginário social brasileiro, inclusive nas representações do Brasil feitas por aqui. A questão dos valores, como vimos, é de extrema relevância para o autor, ocupando grande parte da sua reflexão sobre a atividade científica. Sua preocupação em criar uma distância entre o pesquisador (e seus valores) e o objeto, ou seja, em tornar a ciência social uma ciência objetiva, o levou a adotar o "tipo ideal" como um instrumento de distanciamento na pesquisa social. No entanto, como define modelos de comportamento (ainda que sem a intenção de normatividade), este conceito adquire, muitas vezes, um caráter normativo.

Butler discute como as categorias de identidade também estão sujeitas a mesma questão, pois "estas categorias de identidade nunca são meramente descritivas, mas sempre normativas e como tal, exclusivistas" (Butler, 1998:24). A categoria, na tentativa de designar um conjunto muito grande de diferenças, torna sua utilização uma forma de dominação. Criadas com a intenção de descrever, elas acabam se tornando normativas e excludentes. E tornam-se normativas porque essas descrições não são neutras, mas estão imbuídas de valores porque são criadas socialmente.

No entanto, entendendo o sujeito como construído a partir de um feixe de relações, através de interpretações que se reinterpretam, sob um fundo moral, entendemos que os valores em jogo não são apenas os do pesquisador, mas os valores considerados legítimos, segundo a hierarquia moral que opere na comunidade de discurso e na sociedade das quais participe. Dessa forma, concluímos que, tanto a delimitação do objeto, quanto a própria pesquisa, através

este tipo de verdade e rejeita os juízos de valor; é compreensiva que, aqui, significa perceber o sentido atribuído pelo ator para sua própria ação (Weber, 2005). 
dos métodos utilizados, estarão submetidos a essas contingências, assim como o próprio enunciador do discurso (neste caso, o pesquisador social).

A intenção de refletir sobre o pesquisador enquanto sujeito constituído, trazendo para isso uma leve reflexão sobre a teoria da ciência weberiana, não tem o objetivo de procurar identificar qual dos autores seria mais ou menos científico, tampouco desacreditar os modelos propostos por Weber. O objetivo ao abordar estes pontos, assim como o do trabalho como um todo, é discutir sobre essas relações de poder que nos permeia, passando, inclusive por suas bases morais. Acredito, como Butler, que omitir ou desconsiderar essas bases reforça o efeito político. Procuro, então, discuti-las como forma de dar-lhes visibilidade e, dessa forma, colocá-las também em disputa.

Assim, concordando que o enunciador do discurso não está pressuposto, mas sim imerso em relações que o constituem, pretendo observar agora as bases constitutivas dos nossos enunciadores, para, posteriormente, analisar suas representações a partir dessas bases.

\section{2.}

\section{Duas formas de olhar}

Nos trabalhos de Morse e Schwartzman, as duas representações da cultura ibérica criadas nos permitem perceber duas lentes distintas de interpretação. A compreensão de que as representações criadas podem nos informar muito sobre seus próprios narradores nos ajuda a perceber o caráter constituído destes, desconstruindo seus lugares de fala e, assim, os deixando mais "abertos" à disputa política.

Alasdair MacIntyre (1991) nos ajudará na reflexão deste ponto. Seu tema no livro Justiça de quem? Qual racionalidade?é a justiça - as diferentes concepções existentes e suas respectivas explicações baseadas em padrões de racionalidade. Apesar de o objetivo do autor neste livro ser distinto do tema deste trabalho, sua reflexão tem muito a contribuir, inclusive o seu tema, já que justiça fala de padrões de moralidade - o que é justo está diretamente relacionado a ideais de bem. O próprio autor concorda que seus contextos são, no fundo, sistemas de crenças e valores. 
Assim, um caminho explicativo para os diferentes padrões de justiça existentes, de acordo com MacIntyre, seria que estes se fundam em diferentes padrões de racionalidade. Dessa forma, entendemos que o princípio de racionalidade escolhido conduzirá a uma determinada definição de justiça, e não a outra. No entanto, o autor ressalta que estas diferenças fundamentais são difíceis de resolver,

pois já ao proceder inicialmente de uma maneira, e não de outra, ao abordar uma questão em disputa, aqueles que assim procedem terão suposto que estes procedimentos particulares são o que é racional a seguir. É impossível eliminar um certo grau de circularidade (MacIntyre, 1991: 14).

Ou seja, discutir justiça tendo por base o quão racional ela é será superficial e infrutífero, na medida em que os padrões de racionalidade serão distintos, tornando o debate "circular" 28 . Se o debate entre diferentes padrões de justiça é superficial, a discussão a fundo, no entanto, se torna problemática, pois terá que abordar o que está na base destes diferentes padrões de racionalidade.

De forma semelhante, se quisermos observar as diferenças entre Morse e Schwartzman, atentar apenas para suas representações da cultura ibérica poderá ser superficial. O primeiro a compreende como um sopro de vitalidade na decadente cultura do Norte, enquanto o segundo a vê como um peso de autoritarismo e passado com o qual precisamos romper a fim de avançar. Precisamos, como sugere MacIntyre, observar o que está na base de cada ideia de sociedade e, assim como o autor, perceberemos tratar-se de distintos sistemas de crenças e valores.

\subsection{1.}

\section{Duas formas de compreender o trabalho científico}

Um exemplo do que chamo de "superficialidade" ao lidar com essas representações é que, às vezes, o debate gira em torno de adjetivos que possuem sentidos diferentes para os autores, como se, literalmente, utilizassem gramáticas diferentes. Àquilo que Morse explica, por exemplo, como uma sociedade baseada

${ }^{28}$ É o que acontece, por exemplo, quando, no cotidiano, se discute religião. Considerando cada "fé" como um "padrão de racionalidade", cada manifestação religiosa e explicação teológica só fará sentido e, portanto, será justificável enquanto tal, dentro do seu sistema. Assim, a explicação de fundo para cada manifestação religiosa será a fé - infrutífera para o consenso, já que 
em princípios hierárquicos e de organicidade, para Schwartzman soa como "totalitarismo" (Schwartzman, 1988: 187). Estas diferenças de classificação estão fundamentadas em diferentes bases valorativas.

Outro exemplo que remete a diferentes valores é o peso que Morse e Schwartzman conferem à arte e à ciência, respectivamente. Schwartzman critica o tratamento dado ao que Morse chama os "pretensos intelectuais do Sul". Segundo o autor, Morse despreza a pesquisa acadêmica, a qual chama "método decadente". Assim, de acordo com Schwartzman, para Morse "só aos poetas, romancistas e artistas restaria a tarefa de expressar seu mundo "como centro e não como periferia"” (Schwartzman, 1988: 190). Morse se defende afirmando que Shwartzman tem total confiança na forma acadêmica de conhecimento, enquanto ele não se sente preso a ela, preferindo a variedade de formas de conhecimento. $\mathrm{O}$ recurso aos literários visa reconstruir uma ponte de diálogo com e sobre a sociedade que Morse não acredita ser possível a partir da Academia (Morse, 1989).

Esse aspecto do debate expressa diferentes pontos de vista sobre a produção do conhecimento, sobre quais aspectos são mais relevantes na análise. Morse está atento às questões de ordem cultural, enquanto Schwartzman estaria às de ordem político-econômicas (Oliveira, 2000). Poderíamos dizer, nos apropriando da discussão de MacIntyre, que seriam diferentes "padrões de racionalidade", cuja base tem relação com diferentes concepções sobre o conhecimento e sobre as formas de se conhecer ${ }^{29}$.

Podemos encontrar uma interessante reflexão sobre este tema com Graciela Chamorro (2000). O saber racional, segundo ela, tem por característica o menosprezo do espírito, da sensibilidade e da fantasia, e tem se apoiado numa categoria epistemológica, a saber, o sujeito abstrato universal. Apoiado nessa categoria está também o universalismo, que "sempre consistiu na 'identificação de experiências de um grupo específico de pessoas como argumento paradigmático do humano em geral"" (Benhabib, 1987:91-92 apud Chamorro, 2000). Os que se orientam por esse paradigma tem o argumento de que "sua epistemologia é

cada religião partilhará de uma fé, ou um "padrão de racionalidade" (para usar o termo de MacIntyre) diferente.

${ }^{29}$ Diferenças, inclusive, sobre os objetivos do trabalho intelectual.Segundo Schwartzman, a missão do trabalho intelectual para Morse é elaboração de ideologias, enquanto para si próprio a missão seria desmistificá-las (Schwartzman, 1989: 195). 
baseada na razão pura, abstrata e universal" (Chopp, 1996: p. 147). A crítica, por sua vez, atacará justamente esse universalismo, além do fato de "privilegiar um conhecedor autônomo, capaz de abstração, de elevar-se acima da história" (Chamorro, 2000: 160), cujo apoio epistemológico podemos encontrar no sujeito cartesiano, onde o exterior possui menos relevância, já que "o conhecimento situa-se no indivíduo, nas estruturas da consciência, na capacidade de observação ou na lei natural ou vontade que há dentro do indivíduo" (Chopp, 1996:148 apud Chamorro, 2000: 161). Encontramos referência a este indivíduo também no trabalho de Hall, o qual é descrito como o sujeito Iluminista (Hall, 2011). A autora conclui sua reflexão afirmando que "a busca do rigor foi sempre a busca pela quantificação" e a consequente desqualificação e desprezo do que não se enquadra nesse critério, ou seja, "de outras formas de saber, oriundas do irracional, do intuitivo e do emotivo" (Chamorro, 2000:161).

Esta, talvez, seja uma pista que possamos seguir para analisar o que estaria na base destas distintas formas de olhar encontradas em Morse e Schwartzman. Este último deixa clara, no seu trabalho, sua preferência por "bases empíricas" (Schwartzman, 1988: 186) em contraposição a Morse que, nas palavras de Schwartzman, mostra uma "nostalgia pela totalidade e pelo transcendente" (Schwartzman, 1988: 187). A insistência de Morse em privilegiar aspectos culturais, assim como sua constante referência a obras da Literatura, em oposição às análises mais focadas nas estruturas político-econômicas de Schwartzman, assim como sua predileção pelo método acadêmico ${ }^{30}$, demarcam duas formas distintas de olhar o mundo que nos deixam pistas quanto ao tipo de sujeito que está na base delas.

Voltando a MacIntyre, podemos afirmar que ambos os autores, Morse e Schwartzman, buscam justificar suas crenças racionalmente, até porque o fazem através do debate acadêmico. No entanto, cada um fala de dentro do seu sistema ou, para usar as palavras do nosso autor, a partir de seus respectivos padrões de racionalidade. Os pontos de vistas alternativos, assim, são considerados racionalmente insatisfatórios, porque estranhos ao sistema, como no exemplo que acabamos de explorar: o uso intenso de literários, em detrimento dos acadêmicos,

\footnotetext{
${ }^{30}$ Essa afirmação não significa dizer que Morse não veja nada da economia, tampouco que Schwartzman seja cego em relação à cultura, mas que estas são suas preferências.
} 
soa irracional para Schwartzman, porque distante do seu sistema de justificação, apoiado em elementos mais próximos do quantificável.

Cabe a nós, agora, buscarmos compreendermos de quais "padrões" estamos falando e explorar o "valor fundamental" de cada um deles.

\subsection{2.}

\section{Duas formas de compreender o processo histórico}

Ao final do primeiro capítulo do seu livro, MacIntyre sugere que os pensadores devam ser compreendidos a partir das tradições às quais pertencem. Ou seja, compreendendo a racionalidade com a qual determinado autor opera, poderíamos compreendê-lo melhor, nos seus próprios termos. A leitura dos autores nos permite perceber dois enquadramentos, duas formas diferentes de ver o mundo. Não as penso como "tradições", mas como formas de olhar, como "panos de fundo" que conformam uma eticidade, no sentido de Taylor. Procuraremos, neste tópico, observar a formação destes diferentes padrões com o objetivo de identificar seu valor fundamental.

Para explicar estes padrões, gostaria de retomar o trabalho de Norbert Elias (1991), conforme foi apresentado no primeiro capítulo. Elias explica que o conceito de civilização foi forjado como forma de diferenciar que é ocidental e civilizado, do que não é. Como característica principal deste conceito o autor apresenta sua pretensão universalizante, para a qual contribuem outras duas características: a ideia de processo e a ideia de homogeneidade. Com pretensão universalizante, Elias se refere à pretensão do modo de ser, agir e pensar ocidental tem de se tornar universal. Afinal, civilização é tomada como o grau máximo de um processo de desenvolvimento. Com isso, não apenas é possível, como necessário civilizar-se mais, possibilitando uma hierarquia entre mais e menos civilizados. A ideia de homogeneidade vem de que este conceito diminui a relevância das diferenças, pondo em destaque aquilo que é semelhança. Assim, somada a sua pretensão universalizante, o conceito de civilização tende a rejeitar o diferente que não se encaixe nesse processo civilizatório - que é único.

Em oposição a este, o autor apresenta o conceito de cultura que tem como principal característica a ideia de particularidade. Diferente do conceito de civilização, este procura dar atenção às especificidades em detrimento do 
homogêneo. Difere também por, dessa forma, as culturas não se enquadrarem num processo evolutivo, de mais ou menos civilizados, mas busca-se uma compreensão de suas particularidades.

Os conceitos de civilização e cultura são utilizados aqui como duas formas distintas de se pensar, como duas diferentes formas de ver o mundo. Não pretendo afirmar que Elias disse isso. Pelo contrário, reconheço que seus objetivos eram outros. No entanto, apesar de comumente misturadas, podem ser separadas analiticamente, como dois tipos de olhares ou tipos ideais.

Podemos observar isso no debate entre os autores quando, à página 22 do seu livro, Morse realiza o que chama de um retorno à "pré-história" da América Ibérica. Com este retorno, o autor busca uma compreensão de como as diferentes tradições históricas que identifica - Ibero e Anglo Américas - surgem de uma "matriz moral, intelectual e espiritual comum" e como, entre os séculos XII e XVII, foram feitas opções que definiriam os "diferentes padrões" do que Morse chama de "civilização ocidental" (Morse, 1988). Dessa forma, podemos observar em Morse a possibilidade de coexistência de diferentes padrões da "civilização ocidental”, sem que isso implique em uma ser considerada mais avançada do que a outra.

Percebemos em Schwartzman, diferente de Morse, um único caminho de desenvolvimento possível. No último artigo do "debate", por exemplo, o autor demonstra uma preocupação com a possível incompatibilidade entre uma agenda de modernização e as "tradições culturais latino-americanas" (Schwartzman, 1989: 191). A identificação desta "incompatibilidade" não sugere que a América Ibérica deva procurar outro modelo de modernização, uma alternativa mais "compatível". Pelo contrário, a argumentação final do parágrafo, sobre o perigo de a valorização das "questões culturais" transformarem-se num "etnocentrismo às avessas", nos leva a concluir que só existe um caminho de modernização possível. O posicionamento de Schwartzman, assim como no conceito de civilização, entende a trajetória histórica como um crescendo, próxima da ideia de progresso. Assim, o diferente é enxergado a partir dessa trajetória e nela imaginado, cobrando-se dele alguns ajustes a fim de que se alie e alcance o "moderno".

Podemos encontrar um enquadramento semelhante ao de Schwartzman em outro autor do pensamento político brasileiro, Raymundo Faoro. A sociedade 
ibérica, neste autor, aparece como uma desviante de um tronco único de desenvolvimento - o seguido por Inglaterra e França. Um momento que demostra esse diagnóstico na sua narrativa é quando identifica que Pombal tem a chance de provocar o "engaste" de Portugal na Europa, mas, ao contrário, acaba reavivando as bases do absolutismo medieval (Faoro, 1994:28). Dessa forma, Portugal aparece como um caso frustrado de capitalismo e, suas opções políticas como resultado do obscurantismo e tradicionalismo da classe dirigente.

Tanto Faoro quanto Schwartzman parecem identificar uma única possibilidade de desenvolvimento. Morse também fala de uma cultura em detrimento da outra quando afirma o esgotamento dos padrões de desenvolvimento do Norte. No entanto, neste enquadramento, a América Ibérica surge como outra possibilidade, como uma alternativa, não como a única, ou a correta, à qual a Anglo-América deva igualar-se.

$\mathrm{Na}$ compreensão do processo histórico de Faoro, e também de Schwartzman, existe uma trajetória principal - a trilhada pela Europa (Inglaterra e França) - para a qual todas as outras fluem, ou deveriam fluir, sob pena de permanecer no obscurantismo. Na compreensão de Morse, por outro lado, não existe uma linha de desenvolvimento principal, mas várias linhas simultâneas, onde há trocas e intercruzamentos.

Meu objetivo com estes exemplos é perceber duas formas distintas de conceber o processo histórico: uma, que podemos associar ao conceito de civilização, identifica uma única trajetória de desenvolvimento possível, e, dessa forma, as culturas e sociedades são representadas e compreendidas a partir da posição que ocupam nesta trajetória; a segunda, que podemos associar ao conceito de cultura, não possui esta trajetória como referência. Assim, sua compreensão das culturas e sociedades privilegiará a diferença, a especificidade destas.

\section{3.}

\section{Pano de fundo moral}

Dentre as concepções de sujeito desenvolvidas por Hall, quero destacar duas: o sujeito iluminista e o sujeito sociológico ${ }^{31}$. Ambas as concepções são de

31 Hall identifica, ainda, uma terceira concepção de sujeito - o sujeito descentrado, conforme visto no primeiro capítulo. 
sujeitos centrados, ou seja, possuem um centro no indivíduo, possuem uma "essência" e, dessa forma, ambas possuem uma ideia de identidade que existe antes do discurso. A diferença entre elas reside em que, enquanto no sujeito sociológico o "eu real" é formado na interação com as paisagens sociais exteriores a ele, e por elas modificado, no sujeito iluminista o indivíduo já nasce com determinadas características que serão desenvolvidas ao longo do tempo. A relação com o exterior, assim, é feita a partir do que já é dado desde o nascimento.

Meu objetivo em retomar as concepções de sujeito de Hall é utilizá-las para pensar diferentes olhares, ou melhor, olhares informados por diferentes valores. $\mathrm{Na}$ medida em que concebe o indivíduo como sendo capaz de se distanciar das contingências e, assim, realizar escolhas "desprendidas", podemos considerar que a concepção de sujeito iluminista de Hall tem como valor, ou fundamento, o indivíduo. Já a concepção de sujeito sociológico não nos permite conceber um indivíduo "desprendido" do seu contexto, na medida em que é constituído em grande parte por ele. Dessa forma, podemos considerar como valor fundamental dessa concepção a sociedade. Assim, meu objetivo com a retomada destes conceitos de Hall não é afirmar que Schwartzman opera apoiando-se na ideia de sujeito iluminista, enquanto Morse operaria com a ideia de sujeito sociológico, mas sim que partilham de seus respectivos valores fundamentais. Ou seja, a partir da leitura do debate entre estes autores, podemos concluir que o valor fundamental de Schwartzman é o indivíduo, enquanto para Morse é a sociedade.

Por "valor fundamental" me refiro ao que Taylor afirma como pano de fundo moral, a eticidade que permeia as decisões e posicionamentos dos sujeitos. Louis Dumont (1985) também trata o indivíduo e a sociedade como valores, quando descreve duas espécies de sociedade: "Quando o indivíduo constitui o valor supremo, falo de individualismo; no caso oposto, em que o valor se encontra na sociedade como um todo, falo de holismo" (Dumont, 1985: 37). Dois tipos de sociedade, então, de acordo com o que seja seu valor fundamental. Nesse sentido, podemos observar em Morse a preferência pelo tipo de sociedade cujo princípio organizador é comunitário, um "comunitarismo rousseaniano" que, segundo o autor, estaria contido na cultura política ibérica. Já em Schwartzman, podemos 
observar a preferência por sociedades cujo princípio organizador é o individualismo, que identifica na sociedade anglo-saxã $\tilde{a}^{32}$.

Butler (1998) afirma que toda teoria postula fundamentos e, nas palavras da autora, "os fundamentos funcionam como o inquestionado e o inquestionável em qualquer teoria” (Butler, 1998:16). É nesse sentido que compreendo o indivíduo e a sociedade, para Schwartzman e Morse, respectivamente. Estes são os elementos que não estão em debate, são inquestionáveis, são seus universais. Todos os argumentos utilizados pelos autores preservam este elemento fundamental. A partir deste valor fundamental distinto, surgirão diferentes concepções de liberdade, de organização do Estado e, assim, diferentes valorações para as sociedades que observam. Não encontraremos nossos autores afirmando estes valores que lhes atribuímos. No entanto, podemos afirmá-los pelas sociedades as quais defende, ou pelas críticas que fazem ao seu outro. Neste sentido, observando suas representações, entendo que estamos analisando os próprios autores, seus modos de ver, seus valores. Afinal, falar do outro é falar de si. Vejamos isso em suas próprias palavras.

Morse, buscando compreender melhor o posicionamento ibérico, distinto do inglês, diante das revoluções científica e religiosa, explica que, neste período, os objetivos comuns eram decididos pelo Estado, que era composto por uma intelectualidade católica. Dessa forma, não era estranho àquela sociedade viver sob princípios que, baseados na teologia, emanavam de um poder central. Essa situação se contrasta com a inglesa, onde a responsabilidade pela eleição de objetivos comuns, retirada do Estado, fora atribuída "a um mercado supostamente 'livre' de ideias e prescrições privadas, agora tratadas como 'mercadorias"” (Morse, 1988: 38). Podemos observar neste trecho de Morse, dois ideais de liberdade, os praticados na Inglaterra e na Espanha daquele período. Enquanto na primeira livre é o indivíduo que pode ser responsabilizado por seus atos, não tutelado, cujo resultado fica a cargo do "mercado", na Espanha essa liberdade é garantida justamente pela intervenção (ou tutela, depende do ponto de vista) do Estado na organização da sociedade, decidindo não apenas os meios, mas também

${ }^{32}$ Não confundir o ideal comunitário presente em Morse com a ideia de comunitarismo desenvolvida, por exemplo, por Gisele Cittadino em Pluralismo, Direito e Justiça Distributiva: elementos da filosofia constitucional contemporânea. Rio de Janeiro: Lumen Juris, 2000. 
os fins. Centrado no Estado, o pensamento político na Espanha barroca compreendia a liberdade não como os limites de imunidade para o indivíduo, mas como a obediência voluntária ao poder constituído.

Morse nos deixa perceber seu valor fundamental quando, analisando a penetração dos princípios do liberalismo burguês em terras ibero-americanas, critica a visão de mundo criada. Segundo o autor, esta influência trouxe uma limitação ao campo de visão social do indivíduo, que só consegue olhar para si mesmo: “as pessoas já não 'compõem' um sistema, simplesmente 'fazem funcionar’ o sistema em benefício próprio” (Morse, 1988: 145). Fica claro aqui o que deveria "vir primeiro" para o autor, ou seja, o "sistema", ou a sociedade. As "pessoas" devem funcionar para o "sistema", e não o "sistema" para as "pessoas". Nesse sentido, o autor identifica no rousseanismo ibérico o contraponto positivo ao individualismo anglo-saxão (Morse, 1988: 93).

Sobre este ponto, Shwartzman critica Morse afirmando que este "não esconde sua simpatia pela cultura política baseada no princípio arquitetônico, na hierarquia, na existência de uma Gemeinschaft que precede os indivíduos e lhes dá identidade" (Schwartzman, 1988: 187). Eu diria que sim, ele simpatiza com este tipo de sociedade. Porém, a crítica de Schwartzman, aliada à associação que o autor faz desta "cultura política" com o nazismo, o stalinismo e o regime franquista, soa como se essa simpatia fosse "criminosa", "abominável". Ele assim a considera porque tal cultura política toca no que Schwartzman considera intocável - o indivíduo; ela o coloca em segundo plano. Para Schwartzman, uma ordem social calcada na liberdade individual, nas formas da cultura liberal anglosaxã, é o antídoto à tentação autoritária da herança ibérica.

Dessa forma, percebemos, como Butler afirma, que ambos os autores tem um ponto intocável em suas teorias. Schwartzman tem seu valor fundamental no indivíduo e, assim, todo argumento, toda proposta política que toque na autonomia deste, ou nos seus direitos individuais, não será digna de consideração - estará, portanto, no terreno da "irracionalidade". De forma semelhante, Morse não admite nenhuma proposta política ou argumento que coloque o indivíduo em primeiro lugar, em detrimento da sociedade. Este autor não aceita nada que quebre 
a organicidade que, para ele, não pode ser gerada de dentro para fora (ou seja, do indivíduo para o todo), mas deve ser gerada do todo para o indivíduo ${ }^{33}$.

Conforme MacIntyre afirma, sempre falamos de dentro de uma tradição. Não existe um lugar neutro, uma posição fora do discurso da qual possamos analisar os demais discursos e representações (Foucault, 1999). Butler (1998), por sua vez, afirma que toda teoria postula fundamentos que são mobilizados como inquestionáveis, que, mobilizados como universais, pretendem-se acima das relações de poder. Essa posição, no entanto, de acordo com a autora "disfarça e amplia o próprio poder", justamente por colocar-se como inquestionável (Butler, 1998:16). Dessa forma, Butler sugere que qualquer premissa pode ser questionada e tornada contingente, apontando, assim, para a abertura dessas categorias, tornadas um "lugar de disputa política permanente" (Butler, 1998:17). De acordo com Zizek (2006), o conflito é inerente à política e esta não pode ser compreendida sem essa dimensão. Para o autor, a tentativa de suprimir a dimensão do conflito cerceia a liberdade do indivíduo, pois sempre será feita em nome de um universal, ao qual todos os indivíduos deveriam submeter seu particular.

Diante destas questões, MacIntyre afirma sua forma de análise: a concepção relativista. Afirma primeiro que todo padrão de racionalidade é criado, e só pode ser dessa maneira, dentro da tradição. Assim, por este motivo, as divergências entre elas - as tradições - não podem ser resolvidas racionalmente. Os padrões de racionalidade são distintos; e não há um lugar do qual se possa falar fora, alheio a qualquer tradição. Dessa forma, de acordo com a concepção perspectivista, as tradições devem ser encaradas como perspectivas diferentes e complementares, não rivais e mutuamente excludentes.

D'Avila (2012), por sua vez, apresenta o conceito de intertradicionalidade: processo de choques e embates entre as tradições, que "permite que as verdades, antes tidas como arcabouço comum de uma tradição, se transformem no tempo, a partir do reconhecimento da minha limitação em traduzir". Intertradicionalidade, nesse sentido, sugere uma lente que não se entende absoluta e preza por colocar as

${ }^{33}$ A diferença entre os dois é que Morse parece mais pluralista, aceita a existência de outros tipos de sociedade e organização política, embora tenha a sua preferência. Schwartzman, ao contrário, não admite inclusive ter "simpatias", já que não vê a possibilidade de outras formas de organização. 
demais lentes em "disputa": "as mutações ocorrem no entrechoque tanto 'inter' quanto 'intra' tradições", trazendo a possibilidade de uma "teoria do conhecimento não dogmática, capaz de conceber a ideia de verdade como processo, como construção" (d'Avila, 2012: 199).

\subsection{1.}

\section{Representação como espelho}

Como já dissemos, de acordo com Dumont, indivíduo e sociedade são valores que estão na base de dois tipos de sociedade: individualista e holista, respectivamente. Acredito que possamos afirmar aqui, com alguma segurança, que a sociedade ibérica tem sido compreendida como holista, assim como a anglo-américa e as sociedades da Europa central (referenciais para Schwartzman), como individualistas. São duas molduras de enquadramento do mundo distintas, que podem ser compreendidas, sob a perspectiva tayloriana, como "panos de fundo" que conformam uma eticidade. Não as vejo como duas formas de compreensão de mundo que se sucedem no tempo, mas que coexistem. A existência do próprio debate mostra isso. Essas formas de pensar são mostradas geralmente como pertencendo a uma linha de "evolução" do pensamento social, onde a concepção individualista sucederia uma concepção holista de sociedade (vide Dumont, por exemplo). Não penso assim. Penso que estas são formas de pensamento que coexistem. São valores anteriores que, por isso mesmo, enquadram o olhar e a análise, mas são também o dever ser, o ideal.

Neste ponto podemos chamar atenção para a relação existente entre o autor e o modelo de sociedade pelo qual simpatiza. Na conclusão do segundo capítulo deste trabalho, destacamos o fato de que ambos partem de uma situação de desencanto com sua própria sociedade. Morse conclui seu livro afirmando que, num momento onde os ideais que alimentaram as sociedades ocidentais parecem ter chegado ao esgotamento, o pluralismo e a visão de todo, características da tradição ibérica, surgem como alternativa civilizacional ao Norte (Morse, 1988). De forma semelhante, Schwartzman, em desencanto com o que poderíamos dizer ser a sua própria cultura, a cultura ibérica, afirma que as sociedades ocidentais "ainda preservam um repertório de criatividade, pluralismo e capacidade de compromisso moral e ético" bem distante do "provincianismo e corporativismo" 
da América ibérica (Schwartzman, 1988: 191). Ambos encontram no seu outro a solução para o desencanto que observam em suas próprias sociedades. É neste sentido que afirmamos que a representação que fazem das sociedades que estudam revelam tanto ou mais sobre eles próprios. Seus ideais de sociedade são, também, seu dever ser.

Neste capítulo, procurei desenvolver a ideia de que os sujeitos são constituídos, e o são sobre um pano de fundo moral (Butler, Taylor). Assim, partindo da ideia de que os sujeitos e as identidades são construções sociais, produzidas no embate, foram incluídos nessa reflexão os próprios autores, Morse e Schwartzman, que, enquanto sujeitos que pesquisam, estão sujeitos às relações de poder e imersos num ambiente moral. Também busquei analisar as diferentes formas de olhar dos nossos autores. Partindo do trabalho de Alasdair MacIntyre (1991), procurei compreender as molduras utilizadas por Morse e Schwartzman. 


\section{5}

\section{Considerações finais}

Neste trabalho procurei desenvolver o ponto central de que as representações da cultura ibérica são criadas discursivamente e, como discursos construídos em meio às relações de poder, estão em constante disputa pela posição de narrativa vencedora. Neste jogo, as identidades são, ao mesmo tempo, objeto e produto destas representações, na medida em que não podemos conhecer identidades fora do discurso. Essas identidades estão em disputa num ambiente moral, onde os próprios pesquisadores, como sujeitos constituídos, no sentido de Butler, também possuem seus ideais de boa vida.

Dessa forma, procurei, inicialmente, apresentar a perspectiva pela qual o objeto é compreendido, através de uma reflexão sobre produção dos discursos, representação e construção de identidades. Expondo meu enquadramento do tema, procurei, em seguida, apresentar o debate dos autores, compreendidos como representações da cultura ibérica que conformam identidades em constante disputa. O objetivo perseguido foi o de observar que, quando estes autores representam essas sociedades, o fazem a partir do seu ponto de vista que, conforme desenvolvo em outro momento do trabalho é, em grande medida, conformado por seus respectivos enquadramentos.

No capítulo Discurso, representação e identidade, procurei desenvolver os marcos teóricos gerais que norteiam todo o trabalho, organizados em quatro tópicos principais. No primeiro tópico, Saber e poder, procurei desenvolver a ideia de que não existe um saber neutro, pois a produção do conhecimento não pode estar desprendida das demais relações sociais, que estão imersas em relações de poder. Neste sentido, foram discutidos três conceitos, sob a perspectiva de Michel Foucault: poder, como difuso na sociedade, produto das relações sociais; representação, cuja principal contribuição, para o objetivo deste trabalho, foi permitir a reflexão de que não há um lugar fora da disputa do qual seja possível a observação ou a fala - sempre falamos de dentro da representação; e discurso, 
como constructo que pré-ordena o enunciado, veículo não neutro, cuja produção e circulação é controlada, sujeita a determinados procedimentos. Um destes procedimentos, segundo Foucault, é a oposição entre verdadeiro e falso, ponto que foi abordado a partir da distinção que Richard Rorty realiza entre verdade e justificação. Outro ponto relevante na reflexão entre saber e poder foi Edward Said, a partir de sua reflexão sobre o Orientalismo como um discurso que "prédetermina" o que é dito sobre o Oriente, além de o autor colocar este como uma construção do Ocidente.

O objetivo do segundo tópico, Ciências Sociais e modernidade, foi discutir a hierarquização de culturas e sociedades realizada, muitas vezes, na prática das ciências sociais, a partir dos conceitos de "moderno" e "atraso". Para isso, os conceitos de civilização e cultura, de Norbert Elias, foram apropriados como duas formas de pensar, duas lógicas de enquadramento dos processos sociais. O primeiro, privilegiando a homogeneidade, operaria a partir de uma única trajetória de desenvolvimento possível, enquanto o segundo privilegiaria as particularidades e permitiria diferentes trajetórias simultâneas.

O terceiro tópico, História e representação, teve como objetivo pensar o conceito de representação a partir de sua aplicação no fazer historiográfico. No desenvolvimento da reflexão, foram abordadas duas concepções de representação, essencializada e desessencializada. A primeira opera com a ideia de um referente anterior ao discurso, enquanto a segunda entende que o próprio discurso é produtor do que busca representar. Desenvolvemos também, neste tópico, a reflexão de que as narrativas produzidas estão em constante disputa pela posição de narrativa vencedora, retomando, assim, o conceito desenvolvido por Rorty - a disputa não é pela posição de narrativa verdadeira, mas pela de narrativa com mais adeptos.

No quarto e último tópico deste capítulo, Identidade, aprofundamos a reflexão, iniciada no tópico anterior, afirmando as identidades como produtos, e não apenas objetos, da representação. Apresentamos também as três concepções de identidades, a partir de Stuat Hall, assim como seu desenvolvimento histórico da concepção de sujeito. A relação entre identidade e diferença também foi abordada neste tópico, ajudando na reflexão, já iniciada com Said, de que o outro é parte integrante da minha própria definição de eu. 
No capítulo intitulado $O$ debate entre Morse e Schwartzman, apresentei o objeto de análise do trabalho - o "debate" - a partir da perspectiva de que ambos os autores encontram-se em desencanto e encontram no seu outro um contraponto a sua situação. Dessa forma, na medida em que narram a história, criam representações - e, assim, identidades - da Ibéria e, consequentemente, do Brasil. As representações são distintas em termos valorativos. Enquanto para Morse a cultura ibérica representa um sopro de vivacidade, uma alternativa aos esgotados padrões civilizacionais do Norte, para Schwartzman ela simboliza todo o obscurantismo e atraso nos quais a América Latina tem permanecido ao longo da sua história. Destaco dois pontos neste debate. O primeiro, como já foi dito, é a distinta classificação valorativa que os autores fazem da "tradição ibérica". O segundo, a igualmente distinta compreensão que os autores têm do trabalho intelectual e do papel da ciência.

O último capítulo, Sujeitos em Construção, Representações em disputa, é organizado em três tópicos. No primeiro, Sujeitos construídos, procurei desenvolver, a partir de Judith Butler e Charles Taylor, a ideia de que os sujeitos são constituídos, e o são sobre um pano de fundo moral. Assim, partindo da ideia de que os sujeitos e as identidades são construções sociais, produzidas no embate, refletimos sobre o fato de inclusive os pesquisadores, no nosso caso Morse e Schwartzman, também serem sujeitos construídos e, assim, estarem imersos em relações de poder e possuírem um "ideal de boa vida". Dessa forma, a reflexão seguiu na direção que as identidades por eles representadas/ construídas também refletirão um pano de fundo moral.

No segundo tópico do capítulo me detive em analisar as diferentes formas de olhar dos nossos autores. Apoiada conceitualmente em Alasdair MacIntyre, na reflexão que o autor realiza sobre a importância da concepção de racionalidade para a definição de distintos padrões de justiça, analiso o que seriam distintos padrões de análise em Morse e Schwartzman no que se refere a dois itens: duas diferentes formas de compreender o trabalho científico e duas diferentes formas de compreensão do processo histórico.

Por fim, analiso o pano de fundo moral que acredito permear o trabalho dos autores, apoiada nos valores de fundo - indivíduo e sociedade - de duas concepções de sujeito de Hall - iluminista e sociológico, respectivamente. Dessa forma, seguimos a reflexão no sentido de que Morse e Schwartzman possuem um 
valor fundamental em suas teorias, ao redor do qual giram todos os argumentos e críticas, ou seja, ao redor do qual suas representações são construídas. Esses valores são, respectivamente, indivíduo - sua autonomia, e a sociedade - sua organicidade. Concluo o capítulo com o terceiro tópico, Representação como espelho, no qual pude analisar como as representações que os autores fazem refletem seu ideal de boa vida.

O esforço do presente trabalho em refletir sobre a produção dos discursos e sua relação com a formação das identidades se dirige para a afirmação de que estes posicionamentos não são neutros. Há uma eticidade que permeia os posicionamentos dos autores, enquanto sujeitos que são, e, consequentemente, as representações do Brasil. O objetivo dessa constatação, no entanto, não se destina a afirmar se isso é bom ou mau, ou que se deva desenvolver instrumentos a fim de evitar os juízos de valor. Muito pelo contrário. Acredito, concordando com Judith Butler, que esse posicionamento reforça ainda mais o que se tenta evitar.

Ao fim do trabalho espero ter contribuído, ao menos, em duas direções. A primeira, na reflexão de que não existe um lugar neutro de onde se fale sobre o Brasil, ou Ibéria, ou sobre qualquer cultura ou qualquer coisa. Mais ainda do que um lugar neutro, que não existem identidades apolíticas, ou seja, que não sejam forjadas no discurso e, portanto, que não participem de toda disputa dele decorrente. Em segundo lugar, espero, na reflexão sobre o Brasil, ter contribuído na direção de pensarmos a possibilidade de outras representações de nós mesmos, conflitantes, mas não necessariamente auto-excludentes. Acredito que só teremos a ganhar com os embates, e debates, surgidos. 


\section{Referências bibliográficas:}

ANDERSON, Benedict. Comunidades imaginadas: reflexões sobre a origem e a difusão do nacionalismo. São Paulo, Companhia das Letras, 2008.

ARON, Raymond. As Etapas do Pensamento Sociológico. Brasília: Editora Universidade de Brasília, 1982.

ARRIGHI, Giovanni. O longo século XX: Dinheiro, poder e as origens de nosso tempo. Rio de Janeiro: Contraponto; São Paulo: Unesp, 1996.

BARBOZA F., Rubem. Tradição e Artifício: Iberismo e Barroco na Formação Americana. 1 ed. Belo Horizonte: Ed. UFMG; Rio de Janeiro: IUPERJ, 2000.

BENHABIB, Seyla (1987). "O outro generalizado e o outro concreto: A controvérsia Kohlberg-Giligan e a teoria feminista". In: Benhabib, Seyla e Cornell, Drucilla (orgs.) Feminismo como crítica da modernidade: Releitura dos pensadores contemporâneos do ponto de vista da mulher. Rio de Janeiro: Rosa dos tempos, pp. 87-106.

BENEDICT, Ruth. O Crisântemo e a Espada: padrões da cultura japonesa. São Paulo: Perspectiva, 1972.

BERGER, Peter L.; LUCKMANN, Thomas. A construção social da realidade: tratado de sociologia do conhecimento /. 11. ed. - Petropolis: Vozes, 1994.

BOBBIO, Norberto; MATTEUCCI, Nicola,; PASQUINO, Gianfranco. Dicionário de política. 12.ed. Brasilia : Ed Universidade de Brasilia (Edunb); 2004. 2 v.

BRANDÃO, Gildo Marçal. Linhagens do Pensamento Político Brasileiro. Dados - Revista de Ciências Sociais. Rio de Janeiro, Vol. 48, nº 2, 2005, pp. 231269.

BUTLER, Judith. Fundamentos contingentes: o feminismo e a questão do "pósmodernismo". Cadernos Pagu, Campinas, n. 11, 1998. Disponível em http://www.maismulheresnopoderbrasil.com.br/pdf/Sociedade/Fundamentos Cont ingentes O Feminismo e a Questao do Pos Modernismo.pdf. Acesso em 06 dez. 2010. 
CHAKRABARTY, Dipesh. "Postcolonialismo y el artificio de la historia: ¿Quién habla de los pasados 'indios'?" In: MIGNOLO, Walter (ed). Capitalismo y geopolítica del conocimiento. Buenos Aires: Ediciones del Signo/Duke University, 2001, pp.133-170.

CHAMORRO, Graciela. Teologia e representação: Uma aproximação ecofeminista do monoteísmo. In: Cardoso, C. F.; Malerba, J. (orgs). Representações: Contribuição a um debate transdisciplinar. Campinas, SP: Papirus, 2000.

CHOPP, Rebeca (1996). "O conhecimento de Eva. Resistência da teologia geminista às estruturas epistemológicas masculinas-dominantes”. Concilium, $\mathrm{n}^{\circ}$ 263. Petrópolis: Vozes, pp. 145-154.

D’AVILA, Paulo M. Filho. Tradição e Intertradicionalidade. In: MARTINS, Paulo Emílio Matos; MUNTEAL, Oswaldo. O Brasil em evidência: a utopia do desenvolvimento. Rio de Janeiro: Ed. PUC-Rio: Ed. da FGV, 2012.

DREYFUS, Hubert L.; RABINOW, Paul. Michel Foucault, uma trajetória filosófica: para além do estruturalismo e da hermenêutica. Rio de Janeiro: Forense Universitária, 1995.

DUMONT, Louis. O Individualismo: uma perspectiva antropológica da ideologia moderna. Rio de Janeiro: Rocco, 1993.

ELIAS, Norbert. "Da Sociogênese do Conceito de Civilização e Cultura", In. $O$ Processo Civilizador, Volume I. Rio de Janeiro: Jorge Zahar Editora, 1994.

FALCON, Francisco J. Calazans. História e Representação. In: Cardoso, C. F.; Malerba, J. (orgs). Representações: Contribuição a um debate transdisciplinar. Campinas, SP: Papirus, 2000.

FAORO, Raymundo. Existe um pensamento político brasileiro?. Net, Rio de Janeiro, 1994. Disponível em: www.scielo.br/pdf/ea/v1n1/v1n1a04.pdf Acesso em 31 jul. 2012.

Os donos do poder: A formação do patronato brasileiro. 3 ed. rev. São Paulo: Globo, 2001.

FOUCAULT, Michel. A Arqueologia do Saber. 1 ed. Petrópolis, Vozes, Lisboa, Centro do Livro Brasileiro, 1972. 
A Ordem do Discurso: Aula Inaugural no Collège de France.

São Paulo: Edições Loyola, 1999.

A verdade e as formas jurídicas. Rio de Janeiro: Cadernos da PUC/RJ, 1979.

"Las Meninas". In: As Palavras e as Coisas: uma arqueologia das ciências humanas. São Paulo: Martins Fontes, 1999b.

Nietzsche, a genealogia e a história. In. Arqueologia das ciências e história dos sistemas de pensamento. 2. ed. Rio de Janeiro: Forense Universitária, 2008. (Coleção ditos \& escritos).

HALL, Stuart. "Estudos culturais e seu legado teórico". In. Da diáspora: identidades e mediações culturais. Belo horizonte: UFMG; Brasília, DF: Unesco, 2003.

A Identidade Cultural na Pós-Modernidade. Rio de Janeiro: DP\&A, 2011.

HERZOG, Tamar. Identidades modernas: Estado, comunidade e nação no império hispânico, in Brasil: Formação do estado e da nação. São Paulo: Editora Hucitec, 2003. 109-122.

HOLANDA, Sérgio Buarque. Raízes do Brasil. Rio de Janeiro: Livraria José Olympio Editora, 1982.

IANNI, Octávio. Pensamento Social no Brasil. Bauru, SP: EDUSC, 2004.

LANDER, Edgardo. Ciências Sociais: saberes coloniais e eurocêntricos. In: Lander, Edgardo (org.). A colonialiade do saber: eurocentrismo e ciências sociais. Buenos Aires: Consejo Latinoamericano de Ciencias Sociales - Clacso, 2005.

LARAIA, Roque de Barros. Cultura: um conceito antropológico. Rio de Janeiro: Jorge Zahar, 2007, $21^{\text {a }}$ ed.

MACINTYRE, Alasdair. Justiça de quem? Qual racionalidade? Edições Loyola: São Paulo, 1991. 
MALERBA, Jurandir. Para uma teoria simbólica: Conexões entre Elias e Bourdieu. In: Cardoso, C. F.; Malerba, J. (orgs). Representações: Contribuição a um debate transdisciplinar. Campinas, SP: Papirus, 2000.

MATTOS, Patrícia. O reconhecimento social e sua refundação filosófica em Charles Taylor. Revista Teoria \& Sociedade, Belo Horizonte, n. 13.2, julhodezembro de 2005.

MORSE, Richard M. O Espelho de Próspero: Cultura e ideias nas Américas. São Paulo: Companhia das Letras, 1988.

A Miopia de Schwartzman. Revista Novos Estudos Cebrap n.24, julho de 1989.

OLIVEIRA, Lucia Lippi. Iberismo e Americanismo: um livro em questão. In: Americanos: representações da identidade nacional no Brasil e nos EUA. Belo Horizonte: Editora UFMG, 2000. pp. 47-67.

ORTIZ, Renato. Estudos culturais. Tempo soc., São Paulo, v. 16, n. 1, un. 2004 . Disponível em <http://www.scielo.br/scielo.php?script=sci_arttext\&pid=S0103$20702004000100007 \& \operatorname{lng}=$ pt\&nrm=iso> . acessos em 05 dez. 2009.

OUTHWAiTE, Willian; BOTTOMORE, Tom. Dicionário do Pensamento Social do Século XX. Rio de Janeiro: Jorge Zahar Ed.; 1996.

PULINO, Lúcia Helena Cavasin. Richard Rorty e a Questão das Representações em Filosofia. In: Vieira, Liszt (org.) Identidade e globalização: impasses e perspectivas da identidade e a diversidade cultural. Rio de Janeiro: Record, 2009.

RORTY, Richard. Contingency, irony and solidarity. Nova York: Cambrige University Press, 1989.

. Verdade, Universalidade e Política Democrática. In: Souza, José Crisóstomo (org.). Filosofia, Racionalidade e Democracia. São Paulo: Ed. Unesp, 2005.

SAID, Edward. Orientalismo: o oriente como invenção do ocidente. São Paulo: Companhia das Letras, 1998. 
SCHWARTZMAN, Simon. O Espelho de Morse. Revista Novos Estudos Cebrap n.22, outubro de 1988 .

O Gato de Cortázar. Revista Novos Estudos Cebrap n.25, outubro de 1989 .

SILVA, Tomaz Tadeu. A produção social da identidade e da diferença. In: Silva, Tomaz Tadeu (Org). Identidade e Diferença: A perspectiva dos Estudos Culturais. Petrópolis, RJ: Vozes, 2011.

TAYLOR, Charles. As Fontes do Self: A construção da identidade moderna. São Paulo: Ed. Loyola, 1997.

VIANNA, Luiz Werneck.Americanistas e Iberistas: a polémica de Oliveira Vianna com Tavares Bastos. DADOS - Revista de Ciências Sociais. Rio de Janeiro, Vol. 34, nº 2, 1991, pp. 145-189.

. Weber e a interpretação do Brasil. Net, Rio de Janeiro, 1999. Disponível em: http://www.acessa.com/gramsci/?page=visualizar\&id=85. Acesso em 31 jul. 2012.

WEBER, Max. A “objetividade” do conhecimento nas Ciências Sociais. In: COHN, Gabriel. Weber: Sociologia. São Paulo: Editora Ática, 2005.

WHITE, Hayden. "Enredo e verdade na escrita da história", In.MALERBA, Jurandir (org.) A História Escrita: teoria e história da historiografia.São Paulo: Contexto, 2006. p. 191-210.

WILLIAMS, Raymond. Palavras-chave: um vocabulário de cultura e sociedade. São Paulo: Boitempo, 2007.

WOODWARD, Kathryn. Identidade e diferença: uma introdução teórica e conceitual. In: Silva, Tomaz Tadeu (Org). Identidade e Diferença: A perspectiva dos Estudos Culturais. Petrópolis, RJ: Vozes, 2011.

ZIZEK, Slavoj. Elogio da Intolerância. Lisboa: Relógio D’Agua, 2006. 